\title{
Does the Judicial Clean Sweep for the New EU Tobacco Directive Mean a New-Fangled Mirth of May?
}

\author{
By Matthew J. Elsmore*
}

\begin{abstract}
:
This article examines major developments in May 2016 concerning European tobacco law and policy. Focussing on extensive Court of Justice rulings in three key cases, the legal analysis considers the role of the Framework Convention for Tobacco Control as regards the lawfulness and appropriateness of the new EU Tobacco Products Directive. In light of past concerns as to legitimacy and proportionality of EU tobacco controlmeasures and the subsequent emergence of a fundamental rights regime, this paper considers how convincing the Court has been this time in its interpretation of contested measures menthol cigarettes, e-cigarettes and standardised packaging.
\end{abstract}

\section{Keywords:}

Tobacco Products Directive - Court of Justice - EU Law - FCTC - Legal Analysis - Menthol Ban E-cigarettes - Standardised Packaging

\section{$1 \quad$ Introduction}

EU tobacco law and policy has tended not to pass without controversy and comment. And litigation in the wake of a series of EU tobacco directives has traditionally provided pivotal moments in the EU acquis; plenty enough for scholars to dissect and cause even for policymakers to reconsider. ${ }^{1}$ The month of May in 2016 appeared to have some classic ingredients for those perennially addicted to the manoeuvrings of tobacco law and policy: a new Tobacco Products Directive ('TPD') that would come into effect on 20th May;' three separate meaty judgments in 'Poland', 'Pillbox' and 'Philip Morris' delivered by the Court of Justice on 4th May on the lawfulness and appropriateness of that

\footnotetext{
* The author is Associate Professor of Law at Aarhus University, Denmark (mels@law.au.dk). Apart from the author declaring neutrality in all matters tobacco and health, the usualdisclaimer applies. Readers ought to note that this version of the article has been submitted to SSRN as a Working Paper on 13 July 2016. Pending peer review, it is intended for publication in a law journal.

${ }^{1}$ In this regard, see in particular judgments in C-376/98 Germany v Parliament and Council (EU:C:2000:544); C-491/01 British American Tobacco (Investments) and Imperial Tobacco (EU:C:2002:741); C-434/02 Arnold André (EU:C:2004:800); C-210/03 Swedish Match (EU:C:2004:802); and C-380/03 Germany v Parliament and Council (EU:C:2006:772). See also Usher, Case C-376/98, Germany v. European Parliament and Council (Tobacco Advertising) Common Market Law Review 38 (6), 1520-1543, and Ludwigs, Case C-380/03, Federal Republic of Germany v. European Parliament and Council of the European Union (Tobacco Advertising II) Common Market Law Review 44 (4), 11591176, variously discussing the first and second EU tobacco advertising directives.

${ }^{2}$ See Directive 2014/40/EU of the European Parliament and of the Council of 3 April 2014 on the approximation of the laws, regulations and administrative provisions of the Member States concerning the manufacture, presentation and sale of tobacco and related products and repealing Directive 2001/37/EC (OJ 2014 L 127, p. 1).
} 
legislation; ${ }^{3}$ and an unexpected bonus on 19th May was the ruling handed down from the English High Court in 'BAT' which scrutinised new UK legislation (also to take effect on 20th May) in order to implement TPD-plus rules on tobacco product packaging and labelling. ${ }^{4}$

The process of drafting, adopting and implementing the TPD was contentious. Yet the headlines in the aftermath of the Court rulings did not perhaps appear to provide the controversy of old. Perhaps that is a good thing. At first glance all three Court rulings appeared a resounding victory for the European Parliament and the Council and an emphatic defeat for the tobacco industry and TPD opponents, further vindicated by the conclusions reached in $B A T .{ }^{5}$ One thing was certainly clear: there was an immense aggregate of judicial guidance to wade through - from Luxembourg comprising over 300 pages of combined judgments and opinions, ${ }^{6}$ and precisely 1,000 paragraphs from Mr Justice Green's sitting in London. ${ }^{7}$ Rejecting all the claimants' arguments, none of the judges found the contested measures invalid or manifestly inappropriate so as to breach proportionality or fundamental rights. This maybe is not a huge surprise. The most pertinent enquiry would always be: How convincing has the Court been (this time) and what are the effects?

To address these questions and inform wider debates, this review takes the Court judgments as the prime focus. The upcoming account seeks to provide a detailed factual and legal background to the cases in order to later identify and analyse how the Court dealt with the numerous challenges that disputed the validity and suitability of the TPD and compliance of its (contested) new measures with established principles of EU law and fundamental rights, which includes examining primary EU law provisions from the Treaty on the Functioning of the EU ('TFEU') and Charter of Fundamental Rights of the European Union ('EU Charter'). The aim is also to predict the consequences of the cases and in this regard, appropriate attention will be paid to the BAT case throughout. The meat of the discussion revolves around the Court's interpretation on the central substantive features to apply across the European Economic Area ('EEA'): (i) a ban on menthol cigarettes; (ii) a special regime for electronic cigarettes; and (iii) standardised packaging and labelling measures for tobacco products, including removal of all promotional communication and large graphic health warnings.

It is hoped that this examination will inform us about the Union legislature's perennial quest for public health competence as between Member States and the EU so as to address whether the EU

\footnotetext{
${ }^{3}$ See, respectively, Case C-358/14 Republic of Poland v European Parliament and Council ofthe European Union, Case C-477/14 Pillbox 38 (UK) Limited (t/a "Totally Wicked") v Secretary of State for Health and See Case C-547/14 Philip Morris Brands SARL and Others $v$ Secretary of State for Health. These were not joined cases.

${ }^{4}$ See British American Tobacco (UK) Limited and Others v Secretary of State for Health [2016] EWHC 1169 (Admin) (19th May 2016).

${ }^{5}$ See, in this regard, 'The new EU directive on tobacco products is valid,' Court of Justice of the European Union, PRESS RELEASE No 48/16, Luxembourg, 4th May 2016, at http://curia.europa.eu/jcms/upload/docs/application/pdf/201605/cp160048en.pdf [Accessed 1st July, 2016].

${ }^{6}$ For example, in Philip Morris the Advocate General felt obliged to issue a Table of contents in order to navigate her 301 points that followed.

7 The combined Court rulings from the Second Chamber total 524 paragraphs and the opinions of Advocate General Kokott were delivered across 696 points. The English High Court judgment is neatly contained in a mere 386 pages. Yet this scale, impressive as it is, is dwarfed by the thousands of pages of documentation accumulated for proposing and adopting the new TPD itself, much of this comprising scientific and market data. See, in this regard, Elsmore and Obolevich, 'Thank You for Not Smoking: The Commission's Proposal for a New Tobacco Products Directive - Legally Sound, but Does it Hit the Spot?' (2013) 4 European Law Review 552-72.
} 
has emerged as a more important and legitimate actor in implementing and setting legal norms in tobacco product control, and how this affects Member States in terms of the scope for national parliaments to adopt stricter measures beyond the TPD. We will see that a very weighty part of the endeavour has been for the Court to extract the meaning and impact in EU law and policy of binding and non-binding new international sources emanating from the World Health Organization ('WHO').

\section{Factual, Legal and Contextual Setting}

The first case Poland concerned an action for annulment brought by the Republic of Poland and supported by Romania challenging the TPD's prohibition on menthol cigarettes. ${ }^{8}$ The other two cases were references for preliminary rulings from main proceedings before the English High Court: Pillbox was a dispute brought by a UK company of the same name that manufactures and markets electronic-cigarettes ('e-cigarettes') related solely to the new EU rules on such products; ${ }^{9}$ and product standardisation measures of the TPD were subject to a joined action brought by Philip Morris. ${ }^{10}$ Collectively, the actions advanced a lengthy series of technical challenges to the lawfulness and appropriateness of the TPD covering the choice of Article 114 TFEU as valid legal basis in general for the TPD and/or with an emphasis on its use for specific rules regarding menthol, e-cigarettes and standardisation, also in terms of proportionality, subsidiarity, legal certainty, as well as several untested matters related to the EU Charter.

The proposal for the TPD was presented on 19 December 2012 and finally adopted in April 2014 on the basis of Articles 53(1), 62 and 114 TFEU. This followed ordinary legislative procedure and attendant consultations and opinions, bringing an end to a protracted process which had included the resignation of the EU Commissioner initially tasked with steering the legislation. ${ }^{11}$ The TPD represents a substantial modification and entirely repeals the previous directive governing the solely sale of tobacco products. ${ }^{12}$ It adopts differing methods of approximation across various substantive

\footnotetext{
${ }^{8}$ Romania was granted leave to intervene in support of the applicant; and in support of the defendant, Ireland, France and the UK, as well as the Commission were granted to leave to intervene.) Poland brought the action against the European Parliament and the Council of the European Union on the basis of Article 263 TFEU.

${ }^{9}$ In the written part of the Article 267 TFEU process, written observations were submitted by Pillbox, the UK, Spanish and French Governments, the Commission, and European Parliament and the Council of the EU and Commission. The same parties were represented at the oral hearing before the Court on 1 October 2015.

${ }^{10}$ This request had been made in two sets of proceedings brought by Philip Morris Brands SARL and Philip Morris Ltd, and British American Tobacco UK Ltd. Those two actions were joined by the national court into the main proceedings where seven other undertakings were granted leave to intervene in support of the applicants. During the preliminary procedure, written observations were submitted by the applicants in the main proceedings and their seven interveners, as well as the governments of France, Ireland, Poland, Portugal, Norway and the UK, plus the European Parliament, the Council of the European Union and the European Commission, and the same parties were represented at the oral hearing on 1 October 2015, whilst Italy and Hungary also participated in that hearing.

11 See http://www.bbc.co.uk/news/world-europe-20523924 which reports that the Commissioner Borg's predecessor, John Dalli, left the European Commission in 2012 after being linked to a cash-for-influence scandal involving the new TPD [Accessed 1st July, 2016].

12 See Directive 2001/37 of the European Parliament and of the Council of 5 June 2001 on the approximation of the laws, regulations and administrative provisions of the Member States concerning the manufacture, presentation and sale of
} 
fields of application - the Preamble notes: "in light of the different degrees of harmonisation achieved", the directive "provides a first set of basic common rules... in relation to presentation and the packaging". ${ }^{13}$ However, at four times the length of its predecessor the TPD is an ambitious piece of legislation and contains several comprehensive sets of provisions. ${ }^{14}$ Apart from the substantive rules regarding menthol, e-cigarettes and product standardisation already mentioned, the TPD is meant to approximate the laws, regulations and administrative provisions concerning tobacco and related products concerning ingredients and emissions of tobacco products, ${ }^{15}$ security features, ${ }^{16}$ and cross-border distance sales of tobacco products. ${ }^{17}$ On top of extending the regulatory scope of EU law to include tobacco related products including a maiden EEA regime for e-cigarettes, a significant innovation is the emphasis on young people. These intended beneficiaries are emphasised throughout the TPD preamble, and mentioned in the main text as a reference point to frame the legis lation's dualobjective, namely: "to facilitate the smooth functioning of the internal market for tobacco and related products, taking as a base a high level of protection of human health, especially for young people..."18

The new EU tobacco products' regime entered into force on 19th May 2014 and became applicable (subject to some transitional provisions) throughout the EEA on 20th May 2016. ${ }^{19}$ In order to properly implement the TPD, since 2014 the EU Commission has adopted nine legal acts (eight implementing acts and one delegated act) containing the detailed technical rules including the methods to determine (characterising) "flavours" in tobacco products, rules for refillable e-cigarettes, and the appearance of the new health warnings. ${ }^{20}$

The essential legal background to the legislation is revealed in the final part of Article 1 TPD which identifies the new legislation as the Union adopting into EU law its mandatory obligations

tobacco products [2001] L194/26, which was repealed from 20 May 2016 (referred to as the 'previous TPD' or 'Directive 2001/37').

${ }^{13}$ See Recital 53 TPD.

${ }^{14}$ It can be gathered that during the course of 2012, several major adjustments were made to the Commis sion's proposal with various policy options dropped,e.g. vending machine and point-of-sale ban/restrictions, or amended, e.g. regarding smokeless tobacco; see impact assessment s.1.4. Moreover, the final adopted text would have been even more ambitious if not for regressive adjustments in reaching the final text of the proposal, and subsequent amendments by the European Parliament.

${ }^{15}$ See Title II, Chapter 1 TPD, which includes the maximum emission levels for tar, nicotine and carbon monoxide for cigarettes and related reporting obligations.

${ }^{16}$ See Title II, Chapter 2 TPD. The new tracking, traceability and security features are designed to combat illicit supply and trade.

${ }^{17}$ See also Title II, Chapter 3 TPD which continues the prohibition - first provided in Council Directive 89/622/EEC of 13 November 1989 on the approximation of the laws, regulations and administrative provisions of the Member States concerning the labelling of tobacco products - of certain types of tobacco for oral use. However, Article 151 of the Act of Accession of Austria, Finland and Sweden grants Sweden a derogation from the prohibition, and the TPD like its predecessor preserves that legal position. See, in this regard, Case C-468/14 Commission v Denmark (EU:C:2015:504) where the Court ruled that by having continued to authorise the sale of loose 'snus' (oral tobacco), the Kingdom of Denmark had failed to fulfil its obligations under Article 2(4) in conjunction with Article 8 of the previous TPD.

18 See Article 1 TPD.

${ }^{19}$ See Article 29-31 TPD.

20 See, in this regard, http://ec.europa.eu/health/tobacco/products/revision/implementation_en.htm and http://ec.europa.eu/health/newsletter/174/focus newsletter en.htm [Accessed 1st July, 2016]. 
under the WHO's Framework Convention for Tobacco Control ('FCTC'). ${ }^{21}$ Barring Liechtenstein, all EEA States were FCTC Parties amongst a 180-strong membership at TPD adoption (and time of wiring). The United Nations treaty came into effect after the previous directive and was signed on behalf of the European Community in $2003 .{ }^{22}$ It is vital to recognise the point of departure for the unprecedented international consensus achieved through the FCTC. According to the WHO, tobacco use is an "epidemic of global proportions which exerts a catastrophic impact upon health". Moreover, the WHO claims of its own treaty that the FCTC represented a "paradigm shift in developing a regulatory strategy to address addictive substances". As a corollary it is a statement of fact that not only do tobacco companies (no longer publically) dispute or seek to undermine the universal medical consensus as to the harm caused by smoking, this declared epidemic status is the premise for most of the FCTC's substantive provisions which set out to curb smoking and tobacco consumption. Among the TPD's sixty recitals, the various sets of FCTC Guidelines are referred to several times. It is important to note that these are non-binding instructions aimed at FCTC Parties as a way to help them meet their obligations under the respective provisions in areas which coincidentally are covered by the Court's judgments. For instance, the guidelines encourage competent authorities to adopt "plain packaging" for tobacco products and even measures that go beyond those recommended by the guidelines, including in regards to the size of health warnings on the "principal display areas" of tobacco product packets, i.e. the external front and back surface of the unit packaging and any outside packaging. $^{23}$

\footnotetext{
${ }^{21}$ See Article 1 TPD. The FCTC is the first treaty negotiated under the auspices of the WHO, with 180 Parties and 168 Signatories; Adopted by the Conference of the Parties to the WHO FCTC 2005 on 27th February 2003, http://whqlibdoc.who.int/publications/2003/9241591013.pdf [Accessed 1st July, 2016].

22 The FCTC was subsequently approved through Council Decision 2004/513/EC of 2 June 2004 (OJ 2004 L 213, p. 8). Included as ANNEX III to that Council Decision, the EC stated in its interpretative declaration made upon signature of the FCTC and confirmed upon formal confirmation that: "The Community and its Member States declare that a Member State of the European Community whose national constitution or constitutional principles do not permit the introduction of a comprehensive ban on tobacco advertising, promotion and sponsorship may make use of the provision enshrined in Article 13(3) of the Framework Convention on Tobacco Control to accommodate regulations so as to respect national constitutional constraints." In its attendant List of Community acts and programmes contributing to promoting tobacco control on the WHO FCTC website the new TPD was not listed at time of writing. As individual FCTC Parties, some EEA states have issued specialdeclarations; for example, the Czech Republic and Belgium, whereas within the Kingdom of Denmark, the FCTC does not until further notice apply to the Faroe Is lands and Greenland.

${ }^{23}$ At time of writing, eight sets of guidelines had been adopted so far by the Conference of the Parties ('COP') covering the provisions of nine articles of the Convention: Articles 5.3, 6, 8, 9 and 10,11,12, 13 and 14.For our purposes, it is relevant to consider Guidelines for Implementation of Article 11 of the WHO Framework Convention, adopted by the Conference of the Parties at its third session in Durban (2008) FCTC/COP/3(10) ('Guidelines'); Partial Guidelines for Implementation of Articles 9 and 10, adopted by the Conference of Parties to the WHO Framework Convention on Tobacco Control at its fourth session in Punta del Este (2010), FCTC/COP/4(10), and amended at its fifth session in Seoul (2012), FCTC/COP/5(6) ('Partial Guidelines'). Recital 7 TPD (cited in the Court's judgments) states: "Legislative action at Union level is also necessary in order to implement the WHO Framework Convention on Tobacco Control ('FCTC') of May 2003, the provisions of which are binding on the Union and its Member States. The FCTC provisions on the regulation of the contents of tobacco products, the regulation of tobacco product disclosures, the packaging and labelling of tobacco products, advertising and illicit trade in tobacco products are particularly relevant. The Parties to the FCTC, including the Union and its Member States, adopted a set of guidelines for the implementation of FCTC provisions by consensus during various Conferences."
} 
Plain packaging is discussed below, and as we come to see, the TPD is very close to such measures including the ground-breaking sort Australia adopted in 2012 by also exceeding the FCTC Guidelines in certain respects. Whilst the EU Commission has been careful not to appear publicly to encourage any such FCTC-plus national legislation, ${ }^{24}$ it is apparent from the impact assessment leading to the TPD that Australia's FCTC-plus measures in the Tobacco Plain Packaging Act 2011 ('TPPA 2011') was another relevant and inspirational source, along with the evidence of smoking behaviour from that country. ${ }^{25}$ The TPPA 2011 was also instrumental in providing political and legal inspiration for new UK law. Thus, while the three actions for the Court all concerned EU legislation and not measures adopted by Member States, the UK's Standardised Packaging of Tobacco Products Regulations 2015 ('UK Regulations 2015') and BAT must be part of the account, and will be addressed below. ${ }^{26}$ In that case, the English judge characterised the instant litigation as "a full scale attack" on the new UK rules, and hence not dissimilar to Advocate General Kokott's reference to a "general onslaught" of the TPD.

Lastly, we need to view the factual and legal account of the cases and TPD in the wider policy context of public health law in Europe. The impact of the legislation and litigation must be seen beyond tobacco policy due to the semblance of an 'EU lifestyle policy' emerges ${ }^{27}$ - on the regulatory basis of what I refer to as 'paternalism by persuasion' - in responding to the rise in Europe of noncommunicable diseases ('NCDs') affected mainly by unhealthy consumption and behaviour related to certain food and beverage products especially amongst young people.

\section{$3 \quad$ Judicial Outcomes and Reasoning}

The accumulated length of the rulings (plus the opinions), and in particular the breadth of substantive matters of the TPD under examination, means it is sensible to chronologically extract the main features of each judgment. Although only on one occasion in each judgment did the Court explicitly refer to the preceding opinion, reference will be made to the key considerations of Advocate General Kokott, and this will provide material as well for the subsequent analysis.

\footnotetext{
${ }^{24}$ This was apparent when Commissioner Borg was questioned at the Proposal's official launch on 19 December 2012. See, in this regard, Elsmore and Obolevich (n XX above).

25 Tobacco Plain Packaging Act 2011 (Cth); Trade Marks Amendment (Tobacco Plain Packaging) Act 2011 (Cth). See also Tobacco Plain Packaging Regulations 2011 (Cth); Competition and Consumer (Tobacco) Information Standard 2011 (Cth). See the EU Commission's impact assessment of 19 December 2012, accompanying the Proposal for a Directive of the European Parliament and of the Council on the approximation of the laws, regulations and administrative provisions of the Member States concerning the manufacture, presentation and sale of tobacco and related products (SWD (2012) 452 final. For analysis of the impact assessment, the proposal and in particular the law-making process leading to the TPD - referred to by Advocate General Kokott as in place "following tough negotiations and an extremely animated legislative procedure" (see opinion in Philip Morris, point 1) - see Elsmore and Obolevich, n XX above.

26 The UK Regulations 2015 were promulgated by the UK Parliament on 19 March 2015, pursuant to Section 2(2) of the European Communities Act 1972 in so far as the regulations implement the TPD and Sections 94 and 135(2)-(3) of the Children and Families Act 2014 in relation to the other elements of the regulations. See http://www.legis lation.gov.uk/ukdsi/2015/9780111129876 [Accessed 1st July, 2016].

${ }^{27}$ See, in this regard, chapters 7 and 8 in Alemanno and Garde, 'Regulating Lifestyle Risks - The EU, Alcohol, Tobacco and Unhealthy Diets,' Cambridge, 2015.
} 
To begin with, it ought to be stated as unavoidable that various judicial discussions were duplicated. In this regard, it is worth noting that each of the judgments involved discussions on admissibility, with the Advocate General seemingly agitated with the referring court on these matters. ${ }^{28}$ In addition, key preliminary passages were rehearsed in Poland and Phillip Morris, and at several points, done word-for-word. ${ }^{29}$ In particular, the Court stressed that, "Article 114(1) TFEU establishes that the Parliament and the Council are to adopt the measures for the approximation of the provisions laid down by law, regulation or administrative action in Member States which have as their object the establishment and functioning of the internal market." 30 Moreover, in each instance the Court repeated that Article 168(1) TFEU provides that a high level of human health protection is to be ensured in the definition and implementation of all EU policies and activities, and that Article 114(3) TFEU explicitly requires that, in achieving harmonisation, a high level of protection of human health should be guaranteed, and at various other points, subsidiary sources were mentioned including Article 35 EU Charter and Articles 9 TFEU. ${ }^{31}$

\subsection{Ban on menthol cigarettes}

Article 7 TPD concerned the general prohibition on certain 'characterising flavourings' in tobacco products, as part of detailed rules on 'Regulation of ingredients'. Poland supported by Romania, brought the action for annulment of the TPD regarding the ban of menthol cigarettes. In Poland it was disputed that menthol was such a 'characterising flavour', i.e. an additive that imparts a clearly noticeable smell and/or taste during or after consumption, and would be prohibited in the EEA. ${ }^{32}$ The Court rejected the action in whole, comprised of three pleas in law, that the prohibition should not have been based on Article 114 TFEU and that the rules infringed the principles of proportionality and subsidiarity. ${ }^{33}$

The judges sought to explain that 'measures for the approximation' under Article 114(1) TFEU may consist in requiring all the Member States to authorise the marketing of the product or products concerned, subjecting such an obligation of authorisation to certain conditions, or even provisionally or definitively prohibiting the marketing of a product or products. ${ }^{34}$ Through reference to the TPD's recitals, the Court found that on this occasion the EU legislature had decided to adopt uniform rules for all tobacco cigarettes, including roll-your-own tobacco, with a "characterising

\footnotetext{
${ }^{28}$ See Poland at paragraph [20]-[30] (opinion at point [18]-[34]), Pillbox at paragraph [14]-[31] (opinion at point [133][30]), and Philip Morris at paragraph [29]-[53] (opinion at point [133]-[30]).

${ }^{29}$ Pillbox did not concern Article 114 TFEU in terms of legal basis.

${ }^{30}$ See Poland at paragraphs [31] (and up to [39]) and Philip Morris at paragraphs [57] (and up to [65]).

${ }^{31}$ See, for instance, Poland at paragraph [20]-[30] (opinion at point [18]-[34]), Pillbox at paragraph [14]-[31] (Opinion at point [133]-[30]), and Philip Morris at paragraph [29]-[53] (Opinion at point [133]-[30]).

32 See Article 2(25) TPD. At paragraph [65]-[67], the Court notes that the alleged "imprecis e nature" of the concept of 'characterising flavour' is remedied within Article 7(2) to (5) TPD, by three mechanisms for determining which tobacco products contain such a flavouring (including "under Article 2(7) (sic) that the Commission must, at the requ est of a Member State, or may, on its own initiative, determine by means of implementing acts whether a tobacco product falls within the scope of the prohibition of characterising flavours"; the Court actually meant Article 7(2)).

${ }^{33}$ Poland claimed the Court should declare invalid Articles 2(25), 6(2)(b) and 7(1) to (5), the first sentence of Article 7(7), and Articles 7(12) to (14) and 13(1)(c). See Poland (Opinion) at paragraph [11].

${ }^{34}$ See Poland at paragraph [37]-[38].
} 
flavour" and in so doing, had taken into account the "international call" through the FCTC for, in particular, "the removal of ingredients that increase palatability, create the impression that tobacco products have health benefits, are associated with energy and vitality or have colouring properties." 35 As we will see, it is important to note that this formulation by the Court directly reflects upon the wording in Section 3.1.2.2 FCTC Partial Guidelines, a source to which the Court (but not the Advocate General) attributed a "decisive influence".36 The Advocate General noted that these guidelines accorded FCTC States an "extremely broad latitude", in particular they allowed them "to choose between prohibitions and mere restrictions on the use of flavouring ingredients in tobacco products and only contain examples of such ingredients." 37

The Court found that tobacco products containing a "characterising flavour" (whether menthol or otherwise) have certain "similar, objective characteristics and similar effects" as regards initiating tobacco consumption and sustaining tobacco use, i.e. to the extent the flavour masks or reduces the harshness of tobacco smoke. ${ }^{38}$ This finding as to palatability was also based on the FCTC Partial Guidelines, which were used once more to support the conclusion that the EU-wide ban was necessary. Thus the EU legislature could properly make all characterising flavours in tobacco products subject to the same set of legal rules, whereas Poland could not, solely in respect of a particular flavouring, call into question the appropriateness of that prohibition for the purpose of achieving the object of human health protection pursued by it. ${ }^{39}$ The Court concluded: "...menthol, by its pleasant flavour, makes tobacco products more attractive to consumers and that reducing the attractiveness of those products may contribute to reducing the prevalence of tobacco use and dependence among new and continuing users." 40

Poland disputed menthol's role in facilitating initiation of tobacco consumption on the basis that it was not attractive to young people in the EU. However, it was not important for the Court that menthol - as part of a class of tobacco flavourings - might have varying effects across varying consumer categories because the argument that the ban does not contribute to the reduction in the number of smokers, even if proved, could not succeed "since it disregards the preventive function of that prohibition, which is to reduce the initiation of tobacco consumption". ${ }^{41}$

\footnotetext{
${ }^{35}$ See Poland at paragraph [42]-[43], referring to recitals 16 and 15 respectively.

${ }^{36}$ See Poland at paragraph [47].

${ }^{37}$ See Poland opinion at point [81].

${ }^{38}$ See Poland at paragraph [48], and mentioned at several other junctures.

${ }^{39}$ In referring to the Opinion, the Court dismis sed the argument, as such, that "more relaxed rules should apply to products long established on the market", i.e. mentholated tobacco. See Poland at paragraph [51] (Opinion at point [54]). This approach does not apply a contrario on account of the fact that by reason of their novelty, certain products may be subjected to special, if not stricter, rules (citing judgments in Arnold André, C-434/02, EU:C:2004:800, paragraph 69, and Swedish Match, C-210/03, EU:C:2004:802, paragraph 71). Such 'certain products' can be seen to include electronic cigarettes and refill containers, see Pillbox and section 3.1 below.

40 See Poland at paragraphs [48] (based on [44]-[47]) and [56] and [84]. The quote at [53] is a recital of FCTC Partial Guidelines (see n 13 above).

${ }^{41}$ See Poland at paragraph [87]. In the following paragraph, the Court rejected the argument that the ban would lead to the rapid growth in the illicit sale of flavoured tobacco products, because "it must be found that that argument does not take sufficient account of the mechanisms introduced by Directive 2014/40, in particular Articles 15 and 16 thereof, in order to deal with that risk illicit trade."
} 
The Court attached important weight to the significant divergences and the prospect of such divergence between the regulatory systems of the Member States given that at the time of adoption of the TPD some countries had established different lists of permitted or prohibited flavourings, whilst others had not adopted any specific rules in this area. ${ }^{42}$ Article 7 TPD precisely guarded against this. In this regard, the Court cited as an example the fact that Germany had prohibited the placing on the market of menthol capsules. ${ }^{43}$ This judicial interpretation stood even though it was conceded by the Court (as the claimants had argued) that in the short term the TPD's ban on mentholated products would in fact create such obstacles. ${ }^{44}$ It ought to be noted that both the Court and Advocate General briefly noted a transitional period built-in to the TPD. ${ }^{45}$

In comparison to the ban, other measures deemed by Poland as less restrictive would not have been likely to reduce the attractiveness of flavoured and menthol tobacco products, including raising the legal age limit and prohibiting cross-border sales of tobacco products. ${ }^{46}$ The Court held that the ban of menthol was not disproportionate and not manifestly inappropriate: the EU legislature had in fact made sure that the negative economic and social consequences of the ban were limited by properly weighing these against the requirement to ensure a high level of human health protection "with regard to a product which is characterised by properties that are carcinogenic, mutagenic and toxic to reproduction" in accordance with Article 114(3) TFEU. ${ }^{47}$

Whilst the Court stated that the improvement of the functioning of the internal market is not among those in respect of which the EU has exclusive competence, the TPD's dual objectives were still better achieved at EU level - for mentholated tobacco products - because contrary to Poland's claims, the effects of those products were not confined to a small number of Member States. ${ }^{48}$ The

\footnotetext{
${ }^{42}$ See Poland at paragraph [57]-[61]. Here the Court relied on information gathered during the Impact Assessment. See also paragraph [62]-[64].

${ }^{43}$ See Poland at paragraph [28]. See also opinion at point [62]), where the Advocate General noted that, "at the time when the Directive was adopted, there was already, in at least two Member States — Belgium and Germany - even a prohibition of certain menthol capsules in cigarettes, with the result that it was not permitted in any case to place this specific variant of menthol cigarettes on the market there".

${ }^{4}$ See particularly, opinion in Poland at point [80]: "In these circumstances, the Union legislature could legitimately assume that rules on the use of menthol and other characterising flavours in tobacco products would soon be adopted at national level if uniform provisions were not introduced at Union level. This has been emphatically confirmed by Ireland and France in the proceedings before the Court in relation to their respective national practices. The reason for the fact, highlighted by Poland, that in reality hardly any national rules in this regard had been enacted in the EU Member States for a considerable period of time appears to be that the Commis sion had prepared for and initiated the legis lat ive procedure for the adoption of the contested directive within the EU at more or less the same time as the WHO Guidelines appeared." ${ }^{45}$ See (Article 7(14)) TPD, which means for tobacco products with a characterising flavour whose EU-wide sales volumes represent $3 \%$ or more in a particular product category, the prohibition is to apply from 20 May 2020. For both the Court and Advocate-General, this matter was identified as giving the tobacco industry (including tobacco farmers) and consumers time to adapt: see Poland at paragraph [76] (opinion at point [133]).

46 See Poland at paragraph [92]-[96]. As the Court noted, Article 18 TPD already provided for the possibility of prohibiting the cross-bordersale of tobacco products. Poland had also suggested a health warning affixed to tobacco products with a characterising flavours.

47 See Poland at paragraph [102].

${ }^{48}$ See Poland at paragraph [111]-[121].
} 
advantages of this action (rather than at Member State level) had been "clearly and unequivocally" presented in Commission's proposal for the TPD and its impact assessment. ${ }^{49}$

\subsection{New regime for e-cigarettes}

For the first time special rules governing e-cigarettes and refill containers have been introduced. These were addressed in Pillbox. The TPD defined these as products used for consumption of nicotine-containing vapour via a mouth piece, and a receptacle that contains a nicotine-containing liquid. ${ }^{50}$ Article 20 TPD was the directly relevant provision which, inter alia, concerned placing on the market and the labelling of such products. The detailed rules included a duty on manufacturers and importers to submit a notification to the competent authorities for any e-cigarette product (also extending to any 'novel' tobacco product) they wished to place on the national market, which must have been done six months before such placing. ${ }^{51}$ The Preamble stated that this notification scheme was put in place to enable countries to carry out surveillance and control tasks. ${ }^{52}$ In Pillbox it was argued by the claimants that Article 20 was invalid in whole or in part as it imposed disproportionate and unequal obligations on manufacturers and/or retailers of e-cigarettes that distorted free competition, and breached subsidiarity and the EU Charter - to which the Court found that no factors had been disclosed of such a kind as to affect the validity of Article 20 TPD.

The Court reiterated that under EU law comparable situations must not be treated differently and different situations must not be treated in the same way unless such treatment is objectively justified. ${ }^{53}$ In finding that e-cigarettes - referred to in the TPD as "related to tobacco products" displayed different objective characteristics from those of tobacco products (in terms of composition, patterns of consumption), the judges rejected the view that by submitting such products to a separate legal regime (which is less strict than the one applicable to tobacco products) the EU legislature had infringed the principle of equal treatment. ${ }^{54}$

The new regime was held to be proportionate. It was important to acknowledge the novelty of the product and the lack of scientific consensus; hence the EU legislature had to take into account the precautionary principle. ${ }^{55}$ The uncertainties surrounding e-cigarettes amid a growing EU market for such products, compounded by the absence of relevant FCTC sources, ${ }^{56}$ had resulted in a lack of

\footnotetext{
${ }^{49}$ See Poland at paragraph [122]-[123].

${ }^{50}$ See Article 2(16)-(17) TPD.

${ }^{51}$ Article 20 TPD also specifies rules for: refill containers not exceeding a volume of $10 \mathrm{ml}$ and a maximum nicotine

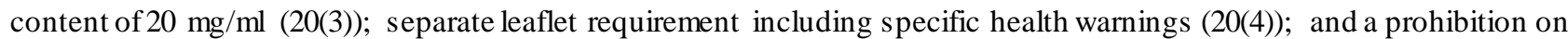
commercial communications and sponsorship (20(5)). Article 2(14) TPD defines a 'novel' tobacco product as one which does not fall into the category of cigarettes, roll-your-own tobacco, pipe tobacco, waterpipe tobacco, cigars, cigarillos, chewing tobacco, nasal tobacco or tobacco for oral use; and was placed on the market after 19th May 2014.

52 See Recital (36) TPD.

${ }^{53}$ See Pillbox at paragraph [35] (citing C-579/13 P and S, EU:C:2015:369 (paragraph 41)).

${ }^{54}$ See Poland at paragraph [36]-[43] which concerns a comparis on to tobacco products. The Court also noted, at [41], that "Thirdly, unlike tobacco products, electronic cigarettes are relatively new products, whose risks to human health still need to be clarified."

55 See Poland at paragraphs [55] (citing C-157/14 Neptune Distribution, EU:C:2015:823, paragraphs 81 and 82) and [50]-[54].

56 The Court referred to the fact that by decision of 18 October 2014 relating to electronic nicotine delivery systems and electronic non-nicotine delivery systems (FCTC/COP/6(9)), the Conference of the Parties to the FCTC had urged '[the
} 
common national rules; a contrario this did not mean that Pillbox could expect, as less restrictive measures, common EU standards at this stage. ${ }^{57}$ Accordingly, obstacles would be presented to the smooth functioning of the internal market and the new rules governing e-cigarettes and refill containers (including the notification scheme, rules about maximum yields, prohibition on advertising and sponsorship) were not manifestly inappropriate or beyond what was necessary to achieve the TPD's dual objectives. ${ }^{58}$

The Court examined the prohibition imposed on companies to promote e-cigarettes and refill containers according to Articles 16 and 17 EU Charter. It was held that the rules did not affect the "essence" of the freedom to conduct a business and the property right. ${ }^{59}$

\subsection{Standardised packaging measures}

Both Advocate General Kokott and the Second Chamber covered a lot of ground in addressing seven extensive questions from the English High Court during Philip Morris, including the menthol ban addressed in Poland. The heart of the dispute and the focus here involved the EEA-wide product standardisation measures. The claimants disputed an adequate legal basis existed, specifically addressed to Articles 7, 18, 24(2) and (3) TPD, and generally the provisions of Chapter II of Title II which relate to packaging and labelling. These included measures on the shape and the minimum content of unit packets, requirements of large health warnings composed of text and graphic imagery, and the prohibition of certain misleading statements on product packaging. ${ }^{60}$ Once more, the Court rejected all the claims.

The discretion afforded in the light of Article 114(1) TFEU meant, "It was thus open to the EU legislature... to proceed towards harmonisation only in stages and to require only the gradual

p]arties to consider banning or restricting advertising, promotion and sponsorship of [electronic nicotine delivery systems]'. See Poland at paragraphs [59] and [114].

${ }^{57}$ See Poland at paragraph [72] concerning Article 20(2) TPD regarding notifications to competent authorities of Member States: "...it should be held that the alternative measure suggested by Pillbox, namely the setting, at EU level, of common standards applicable to electronic cigarettes and refill containers, does not seem, at this stage, to be a possible measure, as the Parliament, the Council and the Commis sion state, since the development of such standards presupposes as a matter of course the existence of sufficiently substantive data concerning the product at issue, which the EU legislature did not have at its disposalat the time of the adoption of Directive 2014/40."

${ }^{58}$ See Poland at respectively, paragraphs [69]-[80] and [81]-[102]. The question about the separate leaflet provision in Article 20(4) TPD was dealt with at paragraph [103]-[108]. At paragraph [112]-[113], the Court referred to Recital (43) to the effect that disparities in these relevant national laws and practices hinder the free movement of goods and the freedom to provide services and create an appreciable risk of distortion of competition. Not only would such disparities likely increase over the coming years - taking into account the rapid expansion of the market for e-cigarettes and refill containers - but consumers (not least young people) were particularly sensitive to advertising.

59 There is little to report on here given the brevity of the Court's "analysis": see Poland at respectively, paragraphs [154][162] and [163]-[164]. To support its finding of accordance with both EU Charter provisions, the Court refers to its earlier discussion at [109]-[118].

60 See Philip Morris at paragraphs [57]-[65]. Unlike the other two disputes, this case also concerned questions as to Articles 290 TFEU and 291 TFEU in respect of the delegation of regulatory and implementing powers to the Commission under the TPD - and these comprised question 4-6 of the referral. However, the Court found these inadmissible given that none of the cited provisions are addressed to the Member States, and therefore do not relate to the implementation of that directive in the domestic legal systems (see paragraph [42]-[46]). 
abolition of unilateral measures adopted by the Member States". 61 The Court and Advocate General noted the different degrees of harmonisation achieved by the TPD, and the main judgment stressed that compliant tobacco and related products should benefit from the 'free movement clause' under Article 24(1) TPD. ${ }^{62}$ Yet given the state of national play, international governance, and the partial harmonisation of the TPD, Member States should under certain conditions retain the power to impose further requirements in certain respects in order to protect public health. Hence according to Article 24(2)) the new TPD was not to affect the right of a Member State to maintain or introduce, under certain conditions, "further requirements, applicable to all products placed on its market, in relation to the standardisation of the packaging of tobacco products. ${ }^{963}$

The "not entirely ambiguous" extent of the power granted to Member States gave rise to several possible readings of Article 24(2). ${ }^{64}$ This had been extensively addressed by the Advocate General (who regarded the various sources as providing a "clarification function" of the partial harmonisation involved ${ }^{65}$ ) and would naturally be taken up in BAT. ${ }^{66}$ The Court favoured a narrow interpretation because among competing constructions "preference should be given to the interpretation which renders the provision consistent with the Treaty rather than to the interpretation which leads to its being incompatible with the Treaty", which was in accordance with the view taken by the EU institutions, as well as France and Portugal. ${ }^{67}$ More stringent requirements (via Article 24(2)) were permitted only in relation to aspects of the standardisation of the packaging of tobacco products which had not been harmonised by the TPD, thus including packaging colour but excluding measures related to combined health warnings. ${ }^{68}$ Such an interpretation was also "consonant with the objective and general scheme" of the TPD. ${ }^{69}$ However, the Court conceded that as a measure for partial harmonisation, whilst eliminating some obstacles to trade Article 24(2) meant inevitably that

\footnotetext{
${ }^{61}$ See Philip Morris at paragraph [63], citing the judgment in Rewe-Zentral, 37/83, EU:C:1984:89, paragraph 20).

62 The so-called 'free movement clause' of TPD is contained in Article 24(1); and see Philip Morris at paragraph [67] (thus, in contrast to Germany $v$ Parliament and Council (C-376/98, EU:C:2000:544) where the doomed first tobacco advertising directive (Directive 98/43/EC) contained no such clause and was eventually annulled by the Court in that judgment.

${ }^{63}$ See Philip Morris at paragraph [67].

${ }^{64}$ Including the expressions "further requirements" and "standardisation". See Philip Morris at paragraph [69].

${ }^{65}$ At some length Kokott surveyed the relevant arguments, observing that as well as the claimants (and their interveners), Ireland, Norway and the UK adopted a particularly broad interpretation of Article 24(2), such that Member States were permitted to impose more stringent requirements on the packaging of tobacco products in any respect, regardless of whether or not that aspect of the packaging has been the subject of harmonisation by EU law (see point [105]-[120]).

${ }^{66}$ See n XX above and Section XX below. As far as lawfulness was concerned, Mr Justice Green stated at [252]: "It follows from the judgment of the Court of Justice [in Philip Morris] that since the TPD and Article 24(2) are lawful, the parasitic or contingent challenge under national law predicated upon the invalidity of the TPD and article 24(2) nece ssarily fails." He then proceeded to consider the question of scope (see also paragraph [266]).

${ }^{67}$ See Philip Morris at paragraph [70].

${ }^{68}$ See Philip Morris at paragraph [69]-[73]. To find otherwise would undermine the harmonis ation effected by the TPD with regard to the packaging of tobacco products (and render the directive incompatible with Article 114 TFEU).

${ }^{69}$ Including to approximate "certain" aspects of the labelling and packaging of tobacco products. See Philip Morris at paragraph [73]-[74]. In the three following paragraphs, the Court also drew on other aspects of the legislation to support his conclusion, including Recitals (47)-(48), (53) and (55), and Article 28(2)(a), which provides that, when the Commission prepares the report referred to in Article 28(1) of the directive, it is to pay special attention to, amongst other things, the 'experience gained with respect to the design of package surfaces not governed by [the] directive'.
} 
not all products whose packaging complies with TPD requirements would be able to move freely on the internal market. ${ }^{70}$

The Court applied the narrow construction as well to Article 24(3) TPD. ${ }^{71}$ In discussing the interaction of Article 24(3) with Article 7 (the central provision in Poland regarding the menthol ban), the Court stated "Under Article 24(1) of Directive 2014/40, those products, where they comply with, inter alia, Article 7, enjoy freedom of movement on the internal market as long as the category of tobacco products to which they belong is not - as follows from Article 24(3) of the directive prohibited, as such, in the Member State in which they are marketed." ${ }^{\prime 72}$

The Preamble of the TPD invited Member States to "introduce provisions providing for further standardisation of the packaging of tobacco products, provided that those provisions are compatible with the TFEU, with WTO obligations and do not affect the full application of this Directive." In addition, various recitals specifically referred to the FCTC Partial Guidelines, ${ }^{73}$ which the Court regarded as "intended to have a decisive influence on the content of the rules adopted in the area under consideration" reflecting the "the EU legislature's express decision to take those recommendations into account when adopting Directive 2014/40". ${ }^{74}$ The FCTC Guidelines state that "the Parties to the FCTC are encouraged to implement measures beyond those recommended by the guidelines," in line with Australia's plain packaging regime under TPPA 2011.

Article 13 TPD regulated 'Product presentation'. The Court interpreted Article 13(1) as prohibiting any element or feature of presentation that is such as to promote a tobacco product or encourage its consumption, even if these are factually accurate. ${ }^{75}$ That interpretation was not found to infringe Article $11 \mathrm{EU}$ Charter or the principle of proportionality: 'the essence of a business's freedom of expression and information is not affected" by Article 13(1) because it "merely controls, in a very clearly defined area, the labelling of those products by prohibiting only the inclusion of certain elements and features" and does not prohibit the communication of all information about the product. ${ }^{76}$ The claimant's argument that $65 \%$ coverage of the surface was not necessary to comply with the EU's international FCTC obligations was rejected. The prohibitions were laid down in law and did not go beyond what was appropriate and necessary in order to achieve the objective of general interest, i.e. the protection of health to be ensured in the definition and implementation of all Union's policies. This finding applied to the requirement that combined health warnings must cover $65 \%$ of

\footnotetext{
${ }^{70}$ See Philip Morris at paragraph [79]-[81] (opinion at point [119]).

${ }^{71}$ See Philip Morris at paragraph [86]-[90]. Article 24(3) TPD provides, inter alia, that a Member State may prohibit a 'certain category' of tobacco or related products, on grounds relating to the specific situation in that Member State and provided the provisions are justified by the need to protect public health, taking into account the high level of protection of human health achieved through the TPD. The Court interpreted that provision as concerning an aspect which was not covered by the TPD's harmonisation measures and which was not, therefore, to be subject to the rules laid down in Article 114(4) to (10) TFEU relating to the introduction of national measures derogating from a harmonisation measure.

72 See Philip Morris at paragraph [93]-[94].

${ }^{73}$ See Partial Guidelines for Implementation of Articles 9 and 10 of the FCTC.

${ }^{74}$ See Philip Morris at paragraph [106]-[126].

${ }^{75}$ See Philip Morris at paragraph [138]-[145] (opinion at point [119]). This outcome, and reasoning, mirrors the judicial analysis of the Court in British American Tobacco (Investments) and Imperial Tobacco, C-491/01, EU:C:2002:741, concerning Article 7 Directive 2001/37 (the predecess or to Article 13(1)(b) TPD).

${ }^{76}$ See Philip Morris at paragraph [151].
} 
the principal display area taking the form of a message and a colour photograph, to the shape of unit packets of cigarettes and the minimum number of cigarettes per unit packet. ${ }^{77}$ It was "undisputed that tobacco consumption and exposure to tobacco smoke are causes of death, disease and disability" and noted the "vulnerability of consumers" - particularly youth - of tobacco products given their nicotine addiction. ${ }^{78}$ The EU legislature had thus not failed to strike a fair balance between the requirements of the protection of the freedom of expression and information and those of human health protection. ${ }^{79}$

\subsection{BAT and the UK Regulations 2015}

The new UK regulations, coming into effect on 20th May 2016, were designed to "reduce the appeal of tobacco products" by making provision for the standardisation of retail packaging of cigarettes and rolling tobacco. Specifically, the regulations sought to implement Articles 13 and 14, and one element of Article 9(3) of the EU directive through Article 24(2). The UK had also sought to implement the FCTC and FCTC Partial Guidelines concerning packaging and labelling. ${ }^{80}$ However, it must be stressed that any kind of meaningful analysis of $B A T$ would require considerable time and space and demand an article in itself reflecting that the tobacco claimants' challenges were grouped under seventeen different grounds and by Mr Justice Green's deliberations filled out 386 pages. Notwithstanding, there are some brief points of relevance we can extract.

It is apparent how the outcome and more so the reasoning in Philip Morris had a direct bearing upon a number of the grounds raised such that the English judge purposely waited for the Court's decision as the instant case saw "national counterparts of the arguments advanced by the same Claimants before the Court of Justice." $" 81$ Unsurprisingly, the claimant's arguments were rejected in London just as they had been in Luxembourg two weeks earlier. The UK Regulations 2015 were held to be valid and lawful in all respects, with no basis to strike them down so that they would not come into effect the very next day (i.e. 20th May 2016). The English High Court was unimpressed by the core claim that the UK Regulations 2015 were unlawful precisely because they purport to be predicated upon Article 24(2) TPD (which was itself unlawful). This argument failed when read in light of the operative part of Philip Morris: "Article 24(2) ...must be interpreted as permitting Member States to maintain or introduce further requirements in relation to aspects of the packaging of tobacco products which are not harmonised by that directive."

Article 24(2) TPD was interpreted by Mr Justice Green as having a broad scope and included in particular public health grounds. This interpretation resonates with the FCTC approach and the earlier view of the Court. In going beyond the TPD - as it was clearly permitted to do so under Article 24(2) - the UK legislature had created an amalgam between the FCTC non-binding guidelines and TPPA 2011 as regards labelling and packaging of tobacco products. The UK Regulations 2015 prescribe the sole colours that are permitted to be used on the external and internal surfaces of the retail product packaging - described by the industry as "a drab brown with a matt finish". ${ }^{82}$ The

\footnotetext{
${ }^{77}$ See in this regard, Article 8-10 and 14 TPD. See Philip Morris at paragraph [138]-[145] (opinion at point [119]).

${ }^{78}$ See Philip Morris at paragraphs [152] and [160].

${ }^{79}$ See Philip Morris at paragraph [161].

${ }^{80}$ See Partial Guidelines for Implementation of Articles 9 and 10 of the FCTC.

${ }^{81}$ See $B A T$ at paragraph [40].

${ }^{82}$ See $B A T$ at paragraph [57].
} 
uniform packaging measured extended to the material that packets must be made from, the shape that the packet must be, what openings are permitted and the minimum amount of cigarettes permitted in each individual packet, as well as that any symbol or figurative trade marks can no longer be used at all either on packaging or on the tobacco products themselves, whereas the word or name trade marks can at least be used albeit only in a highly circumscribed manner. ${ }^{83}$

The principal grounds of challenge in BAT concerned evidence (that the process by which the evidence was collected which led the Secretary State for Health to lay draft Regulation before Parliament was biased and unfair), proportionality (that the UK Regulations 2015 were unsuitable and will in fact be counter-productive and harmful to health) and breach of fundamental rights (the violation of the fundamental right to respect for property (notably trade marks, including copyright and goodwill)). It was held that the UK law was lawful when promulgated by Parliament and remained so in the light of the most up-to-date evidence, finding that on the evidence there was (when the law was promulgated and also occurring at time of the ruling) cogent and substantial evidence supporting the proportionality of the UK Regulations 2015. In regard to trade mark law, it was conceded that the new regime would substantially limit and restrict the use of private rights: "It is undeniably correct, as the Claimants contend, that the Regulations will exert substantial limitations upon the tobacco companies' use of their intellectual property rights." 84 Still, it was found that the UK rules had exerted such substantial interferences for entirely proper and legitimate reasons and struck a "fair balance" between the right to property and opposing public health interests and rights.

Equally important were Mr Justice Green's reservations as to areas of "cursory" and "conclusionary" reasoning by the Court (in Philip Morris), including the analysis of proportionality and fundamental rights. I would add that in analysing any of the national applications of the policy room left by Article 24(2) as regards standardisation, which includes packaging colour but excludes health warnings, one would need to examine such measures to the provisions of Article 13 TPD, i.e.

\footnotetext{
${ }^{83}$ See interalia in this regard, Regulations 3-4, 7-8 and 10 UK Regulations 2015.

${ }^{84}$ See $B A T$ at paragraph [248]. The ruling should be carefully analysed beyond compliance with domestic constitutional law. It should be noted that French plain packaging legislation was upheld as constitutional by France's Constitution al Council; see Decision n.2015-727 DC of 21st January 2016 http://www.conseil-constitutionnel.fr/conseilconstitutionnel/francais/les-decisions/acces-par-date/decisions-depuis-1959/2016/2015-727-dc/decision-n-2015-727-dcdu-21-janvier-2016.146887.html [Accessed 1st July, 2016]. See also JT International SA v Commonwealth of Australia; British American Tobacco Australasia Ltd v Commonwealth of Australia [2012] HCA 30 (15 August 2012), where the High Court of Australia (the supreme court), in reviewing the constitutional muster of TPPA, rejected legal claims by tobacco companies that the domestic regime violates the Australian Constitution, namely acquisition of property (including trade marks) by the Australian government on other than "just terms" (s ee in this regard, Voon, 'Acquisition of Intellectual Property Rights: Australia's Plain Tobacco Packaging Dispute' (2013) 2 European Intellectual Property Review 113). Moreover, examination is needed of in light of global trade and intellectual property laws; we still await the WTO's reply to a formal complaint lodged by Ukraine initiated first by consultations with Australia on 13 th March 2012 concerning these plain packaging rules, with a panel subsequently composed on 5th May 2014; see DISPUTE DS434 'Australia - Certain Measures Concerning Trademarks and Other Plain Packaging Requirements Applicable to Tobacco Products and Packaging'. For current status of this and the four related disputes (DS435, DS441, DS458 and DS467) go to https://www.wto.org/english/tratop_e/dispu_e/cases_e/ds434_e.htm [Accessed 1st July, 2016]. It should be noted that a power to regulate on health grounds is already secured, arguably, by WTO law which may involve adverse effects on intellectual property rights, including trade marks. See the Agreement on Trade-Related Aspects of Intellectual Property Rights.
} 
to the effect tobacco products shall not give a misleading or deceptively positive presentation. Though mentioned by the Advocate General, this was not covered in the main judgments.

Given the political context of the tobacco control discussion, it is worth noting that for the claimants it was regarded as significant that when the UK notified the EU Commission in August 2014 of its intent to issue the regulations (as obliged to under the adopted TPD), certain Member States served detailed opinions objecting to the (then) draft Regulations; in fact $11 \mathrm{EU}$ countries issued such objections. ${ }^{85}$ In $B A T$ the UK government acknowledged this fact but stated that many Member States had not so objected. ${ }^{86}$ Whilst silence is hardly probative, the UK Regulations 2015 could be argued to have marked a trend among certain European countries including Ireland and France to adopt and formally consider packaging measures based on a FCTC-plus standard. ${ }^{87}$ Such measures were, at time of writing, under official consideration in six other EEA nations. ${ }^{88}$

\section{$4 \quad$ Main Analysis}

One could imagine an EU legislature (specifically DG SANCO as architects of the TPD) very happy with events both in Luxembourg and London at the summer's end 2016 (of course I'm not referring to 'Brexit'). The new EU law framework for tobacco and tobacco related products will bring major changes across Europe to what is sold and how - especially as to their taste, look and feel and the manner of presentation. We know that: (i) cigarettes that are potentially attractive to young people through fruit-flavoured additives of fruit or menthol - will not be allowed anymore (or at the very latest not after 20 May 2020); (ii) the rising market demand for e-cigarettes may be (temporarily) halted by the new EEA-wide regime; and most significantly, (iii) tobacco product packages will be standardised in shape and have to carry large combined health warnings that graphically remind the public of the risks of smoking. The latter measures forbid any kind of promotional communication, even if factual or accurate.

We should first consider where the latest rulings stand in the chronology of CJEU case law. We are a long way from the aborted attempt at tobacco policy harmonisation following the Court's annulment finding more than a decade ago. ${ }^{89}$ The acquis has moved on from Tobacco Advertising I,

\footnotetext{
85 These were Bulgaria, Czech Republic, Greece, Hungary, Italy, Lithuania, Poland, Portugal, Romania, Slovakia, and Spain.

${ }^{86}$ See $B A T$ at paragraph [122].

${ }^{87}$ Whilst such measures were adopted in Ireland but were awaiting commencement date, France adopted plain packaging legislation on 17th December 2015 that came into force on 20th May 2016; See also Bill relating to health, no. 2302, deposited October 15th, 2014; amendment AS1408 on plain packaging approved by National Assembly Social Affairs Committee, March 18th, 2015, final approval by Parliament December 17th, 2015. For the bill, see (the health bill contains measures beyond tobacco control): http://www.assemblee-nationale.fr/14/ta/ta0650.asp and Constitutional Council [France], Loi de modernisation de notre système de santé [Law to modernize our health system].

${ }^{88}$ According to the FCTC website and information provided on 19th May 2016 by the Canadian Cancer Society, plain packaging was under formal consideration in Belgium, Finland, Hungary, Norway, Slovenia and Sweden (as well as equivalent laws or public consultations in effect or soon to be in several non-EEA countries, including Canada, New Zealand, Singapore and South Africa). See http://www.fctc.org/images/stories/PlainPackagingStatusCCS 190516.pdf [Accessed 1st July, 2016].

${ }^{89}$ See Hervey (2001) 'Up in smoke? Community (anti)-tobacco law and policy', European Law Review 26: 101-25.
} 
the initial shockwaves of which have long since subsided and possibly were not as profound as many predicted, pegged back methodically in follow-up disputes and a second successful attempt at drafting legislation. ${ }^{90}$ In hindsight some EU law scholars have come to characterise that decision as mere "guidance" and "limited to its own facts" and even as a "false dawn".91 Still, aspects of Tobacco Advertising I possess precedential value and numerous references to that case and the several other leading tobacco cases were found in the latest judgments and especially the opinions. The importance of tobacco litigation continues to extend well beyond tobacco control as a review of other case law and legislative drafting will reveal. In these cases, the 'free movement clause' - important all those years ago in its absence - emerged as something the Union legislature had sensibly paid close attention to this time round, and which subsequently received a favourable judicial interpretation from the Court. It is clear that beyond the substantive provisions, it will be the implications of Article 24 TPD, and especially 24(2), that prove most significant for the new TPD. Most important of all has been the timely emergence of a sturdy source of legitimacy in EU tobacco law and policy.

\subsection{EU Legitimacy for Tobacco Control}

For the EU and its protagonists, public health and tobacco laws and policies in particular, have often exposed legitimacy as a broad concept: contentious and difficult to define. Legitimacy in the tobacco policy field, which I have discussed at length elsewhere, comprises several strands including regulatory, procedural and moral legitimacy, and in the end is a complex mixture of legal and nonlegal components. ${ }^{92}$ Regulatory legitimacy has traditionally been a product of EU law: treaty wording and the principles of conferral and subsidiarity, as interpreted and applied by the CJEU and national courts. Most important, the principle of conferral governs the limits of Union competences, as stated in Article 5 of the Treaty on European Union (previously Article 3). This can be seen from the declarations by the 'European Community' accompanying its adoption of the FCTC: "in accordance with the provisions of the Treaty establishing the European Community, and in particular Articles $3(1)(p)$ and 152 thereof, it is competent to adopt measures, which complement the national policies of its Member States, directed towards improving public health, preventing human illness and diseases, and obviating sources of danger to human health... the exercise of competence that Member States have transferred to the Community by virtue of the Treaties is, by its very nature, bound to continuously evolve." 93

This sounds sensible enough. And yet the core scientific knowledge about the major health effects concerning tobacco consumption and smoking behaviour has been uncontroversial for some time; as noted in Section 2, tobacco companies no longer dispute or seek to undermine the universal

\footnotetext{
${ }^{90}$ See C-434/02 Arnold André and C-210/03 Swedish Match (n 1 above).

${ }^{91}$ See, respectively, S. Weatherill, "The Limits of Legislative Harmonization Ten Years after Tobacco Advertising: How the Court's Case Law has become a 'Drafting Guide"” (2011) 12 German Law Journal 827; M. Dougan, "Vive la différence? Exploring the Legal Framework for Reflexive Harmonisation within the Single European Market" (2003) 1 Annual of German and European Law 113; and J. Snell, “'European Constitutional Settlement', an ever closer Union, and the Treaty of Lisbon: Democracy or Relevance?” (2008) 33 E.L. Rev. 619. Compare this literature to for in stance,

${ }^{92}$ See in this regard, Elsmore, 'In Search of Legitimacy in Regulating Tobacco and Smoking' in P Andersen, C Eriksen and B Viskum (eds), Law and Legitimacy (DJØF, Copenhagen 2015), 153-202.

${ }^{93}$ Emphasis added. See http://www.who.int/fctc/declarations/en/ [Acces sed 1st July, 2016].
} 
medical consensus as to the harm caused by smoking. There have not therefore been any major scientific breakthroughs to speak of. Public health competence as regards tobacco policy has remained a matter for national competence; no attributed powers have passed from nation state to EU since the previous EU tobacco products directive. After all, the EU can hardly be accused of merely complementing the national systems, if we consider the whole range of tobacco control policies in place through EU legislation. So what has changed, what has 'evolved'? How then can we explain not only the boldness of innovations and progress under the new TPD, but the apparent consolidation of the overall legitimacy of the Union legislature - confirmed by the Court (on three occasions)?

\subsection{The FCTC - in general}

In my opinion, a critical vehicle for the EU's rejuvenated and reformulated approach to tobacco control comes from an enhanced legitimacy. And I introduced some of the vital sources at the outset. And as it has transpired, the real key to understanding this area of law and policy - and the recent smooth passage of the TPD through judicial review - requires looking beyond the EU and squarely at the FCTC. It is my contention that in analysing the Court's approach, it is the FCTC that has almost singlehandedly strengthened the stock of Union legitimacy both in terms of a legal source and a political mandate for policy in this once troubled field. Moreover, the timing is essential. The FCTC was a particularly judicious arrival, i.e. occurring since the previous (and first) EU tobacco products directive, and its implementation into EU law is thus secured through the TPD, which has answered the "international call" for action.

We should also recall that the EC is one of the 180 FCTC Parties. Next, we must stress the point of reference of the FCTC: for members "to give priority to their right to protect public health" by continuously enacting, revising and updating their tobacco control laws in the light of scientific, market and international developments; this powerful mantra has somehow diffused any lingering legitimacy concerns for the EU and these very words are found in the directive. One could argue that a legitimacy has been clarified as emanating from an a priori right to legislate on the part of the EU because that can be seen as able to justify or explain some of the central conclusions reached.

Additionally, it is well understood that as a general principle of EU law, Union legislation must generally be interpreted in accordance with international law obligations. ${ }^{94}$ Moreover, confirmation of this legal view is found when Mr Justice Green noted in BAT that as regards Article 1 of the First Protocol of the European Convention on Human Rights ('ECHR'), the FCTC has been accepted by the European Court of Human Rights ('ECtHR') as a legitimate basis upon which States may, in principle, derogate from property rights within the confines of the rules regulating the expropriation or control of property rights. ${ }^{95}$ Understandably, that the FCTC was based on the "best

\footnotetext{
94 See Case C-61/94 Commission v Germany [1996] ECR I-3989 (thus at paragraph [52], "the primacy of international agreements concluded by the Community over provisions of secondary Community legislation means that such provisions must, so far as is possible, be interpreted in a manner that is consistent with those agreements.")

95 See BAT at paragraph [151]. This view does represent at least in principle, an interpretation also found in European scholarship. See in this regard, Henning Grosse Ruse-Khan, 'Overlaps and Conflict Norms in Human Rights Law: Approaches of European Courts to Address Intersections with Intellectual Property Rights' in Geiger (ed.) 'Research Handbook on Human Rights and Intellectual Property' Research Handbooks in Intellectual Property series, Edward Elgar, 2015, chapter 5, especially 84-85.
} 
scientific evidence and experience" and "adopted by consensus" was repeatedly referred to by the Court. ${ }^{96}$ Although not explicit in this regard, it is arguable that the FCTC meant that for the Advocate General the EU competence issue - examined as legal basis - is not really the subject of central discussion (anymore), because 'the suitability of Article 114 TFEU (formerly Article 95 EC and Article 100a of the EEC Treaty) as a legal basis no longer plays the central role it did in earlier years, even though certain points of detail continue to be disputed. Interest is now focused on other legal questions, particularly in relation to the principles of proportionality and legal certainty, the principle of subsidiarity and EU fundamental rights." 97 But this does not convincingly explain how it all happened. More illustratively, we can see the role and impact of the FCTC regarding the discussion of divergences in national laws, to which I now turn.

\subsubsection{Article 24(2) TPD and pre-emptory effects}

An enhanced FCTC role as regards the legitimacy of EU approximation measures helps explain the thinking and drafting for Article 24 TPD and an important pre-emptory effect of its influence that catches national action too. Article 24(2) begins with: "This Directive shall not affect the right of a Member State to maintain or introduce further requirements" (emphasis added). ${ }^{98}$ The careful wording affirms the exercise of the principle of conferral in attributing and not attributing certain regulatory powers to the EU, and the resultant batches of national rules as with the UK Regulations 2015. The FCTC has had a dual-effect because it conterminously confirms an existing legislative and legitimate discretion on the part of the Member States, i.e. such a competence gap as may have existed for the EU has never existed at national level. ${ }^{99}$ Member States have only ever attributed limited competences to the EU legislature for adopting public health/tobacco control laws, with national parliaments retaining autonomy as in the case of dealing with non-communicable diseases, and the EU excluded from harmonising in the field (see also Section 4.4 below). ${ }^{100}$ Yet it is apparent that the Court felt this dual-effect of the FCTC was not contradictory but complementary to the Union's regulatory plans.

This reasoning is heavily reliant on another of the Court's findings. The Court agreed with the EU legislature that the (pre-existing and retained) individual discretion for national parliaments meant that there would likely be divergences in national laws over the coming period of time, albeit unspecified. These discrepancies could be expected to increase due to international scientific and

\footnotetext{
${ }^{96}$ See for instance, Philip Morris at paragraph [112].

97 This statement is repeated early on in each of the opinions; see for instance, Philip Morris opinion at point [3].

98 The Court also noted that whilst Article 24(3) was capable of impeding the free movement of products, "Directive 2014/40 is not intended to interfere with the policies of the Member States concerning the lawfulness of tobacco products as such." See Philip Morris at paragraph [88].

${ }^{99}$ Recital (53) TPD uses the expression "retains the power" as regards presentation and packaging measures, as stressed by the Court. See Philip Morris at paragraph [67]. One could also note (although not mentioned by the Court) that Article 168(7) TFEU ensures the continued responsibilities of the Member States for the definition of their health policy, and as we will see, Article 168(5) excludes any harmonisation of the laws and regulations of the Member States measures which have as their direct objective the protection of public health regarding tobacco.

100 The nature of non-communicable diseases, i.e. not inherently a cross-border health threat or product, and involving consumer freedom of choice (to consumer or not), perhaps raises concerns whether the Union legis lature is best placed to respond to local conditions. See in this regard, Elsmore (n $89 \mathrm{XX}$ above).
} 
market developments (a nod to the FCTC) and presumably equating with scientific uncertainty and market expansion or both as was found for e-cigarettes and refill containers. In fact, in Pillbox the convergence of factors was the ground given for a lack of common national rules, thus giving rise to the need for EU harmonisation in light of established case law and the precautionary principle; the Union legislature was entitled to act and not have to wait for scientific consensus (i.e. rather than to await further and clearer evidence, including reviewing the effects of the Australian TPPA 2011) and that otherwise such obstacles would be presented to the smooth functioning of the internal market and free movement of goods. Furthermore, that this would mean potential obstacles to the future free movement of goods sufficiently meaningful for Article 114 TFEU purposes. ${ }^{101}$

In Poland, this judicial interpretation stood even though it was conceded (as the claimants argued) that in the short term the TPD's ban on mentholated products would in fact create such obstacles. ${ }^{102}$ The Court and Advocate General, in order to support the interpretation, cited that Germany had prohibited the placing on the market of menthol capsules at the time of adoption of the new TPD. ${ }^{103}$ Yet, "as far as can be seen, there were no such prohibitions in other Member States at the time" was an acknowledgement found in the Poland opinion though not subsequently the Court's judgment. Did this mean that a partial ban on certain ingredients in one or two Member States was sufficient grounds to ban menthol products EEA-wide? In other parts of the judgments, the Court observed that the subsidiarity principle was not intended to limit EU competence on the basis of the situation of any particular Member State taken individually. ${ }^{104}$ It was barely touched upon that the EU internal market for menthol cigarettes was highly varied: ranging from $25 \%$ market share in Finland to $0.1 \%$ in Greece. ${ }^{105}$ Rather, the fact that some or the vast majority of Member States may

101 Once more, this is not a new approach to judicial interpretation of public health 'harmonisation' measures and dates back, at least, to Tobacco Advertising I.

102 See particularly, opinion in Poland at point [80]: "In these circumstances, the Union legislature could legitimately assume that rules on the use of menthol and other characterising flavours in tobacco products would soon be adopted at national level if uniform provisions were not introduced at Union level. This has been emphatically confirmed by Ireland and France in the proceedings before the Court in relation to their respective national practices. The reason for the fact, highlighted by Poland, that in reality hardly any national rules in this regard had been enacted in the EU Member States for a considerable period of time appears to be that the Commis sion had prepared for and initiated the legis lative procedure for the adoption of the contested directive within the EU at more or less the same time as the WHO Guidelines appeared." 103 See Poland at paragraph [28]. See also opinion at point [62]), where the Advocate General noted that, "at the time when the Directive was adopted, there was already, in at least two Member States — Belgium and Germany — even a prohibition of certain menthol capsules in cigarettes, with the result that it was not permitted in any case to place this specific variant of menthol cigarettes on the market there".

104 See Poland at paragraph [119] (citing to that effect, Estonia v Parliament and Council, C-508/13, EU:C:2015:403, paragraph 53). On this point, the Advocate General noted at point [63], "It should also be mentioned in this connection that the number of Member States which had legislated or had the intention of legislating in the field concerned on the date of the Commission's proposal is not, in itself, decisive for assessing whether the EU legislature's recourse to Article 114 TFEU was lawful if the conditions for recourse to that article were met on the date on which the legislative measure at issue was adopted."

105 See Euromonitor data as presented in Matrix Insight Ltd, Economic Analysis of the EU Market of Tobacco, Nicotine \& Related Products (May 2012), which featured as part of the several reports used by the European Commission in and during the impact assessment process for the proposal to the TPD.

See Poland at respectively, paragraphs [69]-[80] and [81]-[102]. See, to that effect, judgment in British American Tobacco (Investments) and Imperial Tobacco, C-491/01, EU:C:2002:741, paragraph 123). 
not have adopted laws on the basis of scientific uncertainty or market divergence presumably referred to, as in regards to tobacco related products or menthol products, was precisely the reason the EU through the FCTC has pre-empted such national action, i.e. such temporary inaction as the Union legislature (the Commission) saw it in first proposing the ban.

In the discussion about Article 24(2) TPD, it is also relevant to recall from Section 3.3 the Court's concession that Article 24(2) (as a measure for partial harmonisation) meant inevitably that not all products whose packaging complies with TPD requirements would be able to move freely on the internal market (hence rehearsing the concession noted in Poland). ${ }^{106}$ Regarding Article 24(2), some authors have categorised as "complex" the argument published by Philip Morris (and often heard by tobacco companies) to the effect that differences in national packaging rules do not after all constitute an obstacle to free movement because tobacco companies tend to tailor their products to the divergent preferences of European consumers anyway, as seen in tobacco and smoking behaviour across national markets. ${ }^{107}$ The same authors, and I would say rather harshly, qualify such an argument as "slightly disingenuous." They do not elaborate, but it must surely be because such an argument effectively undermines the need for further and more aggressive harmonisation at EU-level to aid functioning of the internal market. Whether the marketing literature which supports the tobacco companies counter-argument is correct in this regard (noting the divergences of tobacco product consumption patterns and hitherto proliferations of brands), ${ }^{108}$ it has been the case that the heterogeneous rather than homogenous "European smoker" has since the first batch of EU tobacco directives been recognized by EU health law commentators as presenting a challenge to the successful impact of a 'pan-European' health (tobacco) policy. ${ }^{109}$

Hence, in spite of the binding obligation on FCTC Parties, i.e. EU Member States, to continuously enact, revise and update their tobacco control laws in the light of scientific, market and international developments, this regulatory approach that has been judicially approved pre-empts the a priori right of national parliaments as regards the TPD's mandatory provisions, though only in relation to those "aspects" of control of tobacco products which it harmonises. In terms of the actual substantive provisions, if one compares packaging measures with the menthol ban and e-cigarettes' regime, there can be little doubt that the EU Member States enjoyed a pre-existing competence to regulate the imposition of branding and promotional restrictions and curbs on tobacco products themselves. Besides, product packaging measures comprising mandatory warnings messages were a critical (albeit controversial) part of the previous TPD, and first established at Union level in much earlier EU legislation in the wake of national regimes dating back to the 1960s and 1970s that evidently coincided with the emergence of new scientific evidence as to the adverse effects of

\footnotetext{
106 See Philip Morris at paragraph [79]-[81] (opinion at point [119]).

${ }^{107}$ See in this regard, Nanopoulos and Yotova, 'Repackaging' Plain Packaging in Europe: Strategic Litigation and Public Interest Considerations, Journal of International Economic Law, 2016, 19, 175-210, at 194-95.

108 See Pollay et al., 'The Last Straw? Cigarette Advertising and Realized Market Shares among Youths and Adults, 1979 1993', Journal of Marketing, Vol. 60, 1996, pp. 1-16; and Krontalis, 'Uncovering Attribute-based Determinants of Loyalty in Cigarette Brands', Journal of Product and Brand Management, Vol. 22, 2013, pp. 104-117.

${ }^{109}$ See in this regard, Devlin et al. Targeting smokers via tobacco product labelling: opportunities and challenges for Pan European health promotion, Health Promot. Int. (2005) 20 (1): 41-49.

See Poland at respectively, paragraphs [69]-[80] and [81]-[102]. See to that effect, judgment in British American Tobacco (Investments) and Imperial Tobacco, C-491/01, EU:C:2002:741, paragraph 123).
} 
smoking. ${ }^{110}$ EEA Member States in their capacity as FCTC Parties were generally free (or freer) in the period leading up to the new TPD to implement binding obligations as well as adopt recommendations through the various FCTC guidelines as they saw fit to match prevailing local conditions.

On reflection, it is understandable and probably sensible that the decisive factors in legislative drafting and the Court's judicial review are qualitative, rather than quantitative. But if we accept that explanation, why did the EU legislature not instead adopt the Article 24(2) approach for mentholated products (option for more stringent standards, as for packaging measures) or leave it to Article 24(3) (prohibit a certain category of tobacco or related products according to specific and localised public health needs) thus enabling Member States discretion subject to the free movement clause in 24(1)? That way, the latitude afforded by the FCTC, notably for non-binding areas, would exist at national level and the TPD rules would have been acting as a partial approximation source like the FCTC Partial Guidelines appear to. This seems all the more sensible given that "flavours" of any kind was not part of the previous EU directive, as well as the plain fact that despite the freedom of national action in that area plus the period of 10 years since the FCTC had been in effect, it appeared that 26 or 27 present EU Member States had not instituted a menthol cigarette ban.

\subsection{The FCTC Guidelines: a non-binding yet "decisive influence"}

Understanding the FCTC has an additional aspect, which turns out to be of much greater interest; namely the consistent, continuous and faithful referral by the judges to the FCTC Guidelines. These guidelines are what we might refer to as a source of "international soft law". My understanding is that this is the first time these particular guidelines have been referred to by the Court. It ought to be noted that there are seven independent sets of FCTC Guidelines, and re-emphasised that they are outside the mandatory scope of the main UN treaty and are meant to primarily signify a source of guidance as to the interpretation of the FCTC's binding provisions: "The guidelines are intended to help Parties to meet their obligations under the respective provisions of the Convention."111 It is not totally clear that the sets of guidelines have equal interpretative status or persuasion - some are listed as "partial" guidelines for instance.

However, collectively the guidelines are meant to indicate best practice for nations and suggest various specific recommendations for policy makers. In BAT the UK Government accepted that although the guidelines were not binding, ever since the UK became a party to the treaty in 2004 it had taken its international obligations "very seriously" and it was deemed important that the treaty's contracting parties had agreed that those guidelines reflected their "consolidated view of a desirable

\footnotetext{
110 As noted in Directive 2001/37, Directive 89/622/EEC (referred to in n 19 above) "established a general warning to be carried on the unit packaging of all tobacco products, together with additional warnings exclusively for cigarettes and, from 1992, extended the requirement for additional warnings to other tobacco products." See Recital 6, see also Article 7 Directive 2001/37 governing 'Product descriptions' which was the subject of litigation in C-491/01 (see n 2 above, and the other case law cited there), it stated, "With effect from 30 September 2003, and without prejudice to Article 5(1), texts, names, trade marks and figurative or other signs suggesting that a particular tobacco product is less harmful than others shall not be used on the packaging of tobacco products."

111 The guidelines cover FCTC Articles 5.3, 8, 9 and 10, 11, 12, 13, and 14 respectively. The latest 2013 consolidated edition of the FCTC Guidelines can be found at http://www.who.int/fctc/guidelines/adopted/guidel_2011/en/ [Accessed 1st July, 2016].
} 
means of fulfilling their FCTC obligations". 112 Most remarkable is not that the FCTC has buffered if not enhanced the Union legislature's legitimacy, but rather that it has done so by reaching beyond its own binding scope so as to influence and affect the design and implementation EU law and policy through its non-binding content. In particular, wen interpreting the TPD, both the Court and Advocate General allocated a "decisive influence" to the various sets of FCTC Guidelines.

Firstly, this allocation was seen in Poland, wherein it became apparent to the Court that "menthol" (or "flavours") was neither mentioned as part of the mandatory FCTC obligations nor had it been anticipated in the previous TPD. The Court consulted the FCTC Guidelines. It emerged that the FCTC Partial Guidelines concerning the 'Regulation of the contents of tobacco products' suggested for FCTC Parties to either impose "mere restrictions" or institute a "product prohibition" on the use of flavouring ingredients in tobacco products. This is despite that those guidelines only contain examples of such ingredients, including a solitary reference to "menthol", and that these guidelines do not relate to mandatory FCTC measures, in contrast to other sets of guidelines. Still, this guidance was enough for the Court to support the EEA-wide menthol ban introduced by the TPD because the judgment and opinion both found, even in these circumstances, that the guidelines had a "decisive influence". 113

Secondly, the "decisive influence" was applied again in Philip Morris to smoothen the Court's interpretation of the TPD's packaging and labelling measures. ${ }^{114}$ This is to be expected having first read Poland (chronologically the first of the three cases) because according to the relevant extracts of the respective guidelines, the WHO states that tobacco products "are commonly made to be attractive in order to encourage their use." This rather trite statement is the policy precursor to the comprehensive sets of counter-measures designed precisely to reduce the attractiveness of such products; it is stated that according to public health grounds "there is no justification" for helping make tobacco products attractive such as permitting including the use of ingredients (such as flavouring agents) and commercial communication on packaging. ${ }^{115}$ When addressing proportionality in light of the FCTC as regards the combined health warnings, the Advocate General acknowledged that neither the FCTC nor the guidelines laid down a specific obligation to allow $65 \%$ coverage of the principal display areas, which follows from Article 10(1)(a) and (c) TPD. Article 11(1)(b)(iv) FCTC prescribes that the warnings shall be no less than $30 \%$ of the principal display areas. However, we need to read on to find the important wording for the judges; namely that the same FCTC provision contains the additional statement that the warnings should be $50 \%$ or more of the main surfaces of cigarette packets. This is a clear example of a set of TPD go beyond the FCTC and its relevant guidelines - the latter adds no more to the main treaty text in Article 11 other than referring to "the evidence that the effectiveness of health warnings and messages increases with their

\footnotetext{
112 See $B A T$ at paragraph [146].

113 As noted in Section 3.1, it should be borne in mind that a further 4-year transitional period exists under the TPD for certain flavoured products up to May 2020 (see Article 7(14) TPD).

114 See Poland at paragraph [47], and Philip Morris at paragraph [111]-[113].

115 It is worth noting that in contrast to the FCTC - and the previous TPD - the latest TPD has removed factual information of packaging relating to TNCO. Thus in preventing the use of accurate or factual information on tobacco packaging and labelling, the TPD goes beyond the FCTC and its guidelines. See Elsmore XXX.
} 
size". ${ }^{116}$ Regrettably, there was also no examination by the Court of why $65 \%$ for combined health warnings should apply in all EEA States as opposed to the mandatory $30-50 \%$ range or $50 \%$ or more option of FCTC. Neither was it mentioned anywhere in the opinions or the rulings that the Commission had originally proposed a combined health warning with $75 \%$ coverage which might presumably have some explanatory force and the reduction could have perhaps been another factor strengthening a non-finding of disproportionality, which would have been helpful (as I come to argue).

As revealing as it is what was said and relied upon, it is equally instructive that throughout the second case in Pillbox the same Second Chamber - on the same day and with the same personnel - was silent as to any such kind of "influence", let alone a "decisive" one. This makes sense because not only are there no relevant FCTC Guidelines for e-cigarettes and refill containers, there are no relevant FCTC provisions at all regarding tobacco related products. Hence, this is not far from the factual scenario before the Court in Poland. Even so, the Court in Pillbox refers to a need "to meet the obligations of the Union under the FCTC" in respect of the new EEA rules governing ecigarette. ${ }^{117}$ Regrettably, the precise nature of these obligations is not clarified in relation to these tobacco related products. One might reasonably ask which FCTC obligations precisely are we talking of? It could be suggested by the fact the TPD regime is new means the Union legislature intended for its provisions to be seen in light of the general scheme and purposes of the FCTC. Another view is that the EU wished to take a lead and act as a 'norm setter' (rather than 'norm taker') going beyond its role as implementing FCTC norms.

In assessing the above discussion, some observers will simply argue that the TPD is meant to implement the whole of the FCTC including its mandatory and non-mandatory parts. And that in any case, the most probative effect of the FCTC - at least for the Court - concerned those TPD provisions which are expressed as mandatory or "binding" under the FCTC. I have expressed doubt as to this view. However, a stronger argument is that the reasoning can be seen as consistent with another important EU law principle: the precautionary approach should be adopted in a policy field entailing political, economic and social choices for the EU legislature, and in which it is called upon to undertake complex assessments, such as tobacco control (public health). Moreover, we can gather from past Court interpretations some sporadic references to WHO views and opinions on health issues, such as when evidence presented by the WHO's International Cancer Research Agency was cited and arguably the Court placed some degree of weight to this. ${ }^{118}$

However, in that solitary instance I found from 1998, only a very limited and isolated weight is afforded the non-binding WHO guidance by the Court. Furthermore, I agree with Mr Justice Green (in his review of Philip Morris during BAT) that it came as a surprise that the Court afforded a "decisive influence" to the FCTC Guidelines, and I would add particularly as it was not a Grand Chamber. We might ask why not a "persuasive" influence instead of "decisive", or as a source of "guidance" as presumably many FCTC Parties would have intended given the variant national attitudes and histories towards tobacco control, consumption and smoking behaviour? A more

\footnotetext{
116 See page 57 consolidated FCTC Guidelines (2013 edition) (see n 103 above).

117 See Pillbox at paragraph [61].

118 Case C-473/98 Kemikalieinspektionen at paragraph [42]. See also See for example, Case 174/84 Commission v Federal Republic of Germany [1987] ECR 1262 at paragraphs [41], [44] and [52] and
} 
moderate approach might be preferred to some EU Member States too; for example, the Czech Republic declared when joining the FCTC that it did not consider the "[FCTC] guidelines adopted by the Conference of the Parties as instruments directly establishing legal obligations under the Convention."19 The latest judicial interpretations by the Second Chamber may have gone well beyond what we have seen before and what we might have expected. In this regard, it might be timely for (EU law) scholars to consider addressing the legal significance of the FCTC and FCTC guidelines in the setting of EU law, a subject that apparently has hitherto not attracted any dedicated analysis. ${ }^{120}$ In the Clove Cigarettes dispute between Indonesia and the United States, the WTO panel referred to the FCTC and its guidelines even though neither was a party to the treaty. ${ }^{121}$

\subsection{Article 168(5) TFEU and the EU's "value system"}

There is further evidence for the pre-eminence of the FCTC and its impact on the Court and Union legislature. In trying to explain the growth in competence manifested by the TPD, there is little to be gained from considering the changes to the Lisbon Treaty resulting in an amended Article 168(5) TFEU. Whilst potentially significant on paper, these have apparently limited relevance in terms of actual harmonisation and actual laws. The changes mean that the EU's primary law public health provision now includes explicit reference to "tobacco". Could it be that the effect of Article 168(5) has increased the relevance of the EU and strengthened its legitimacy as an actor in public health $a s$ regards tobacco control law and specifically the TPD? A positive answer might ease any concerns with the preceding analysis above.

Sadly, the preliminary answer to the first part is we don't know. We do know that Article 168(5) TFEU was not instrumental to the TPD. We also now that the three Court judgments tell us nothing about that article because neither Court nor Advocate General made any independent mention whatsoever of Article 168(5) (nor is it mentioned by the English High Court in BAT). In fact, the only mention came during Poland when the Court restated the well-rehearsed argument presented by Romania that Article 168(5) excludes any harmonisation of the laws and regulations of the Member States in the area of health protection. It is a well-rehearsed claim because that caveated wording has always been part of the provision, formerly Article 152 EC Treaty (and previously Article 129 EC Treaty following the breakthrough of the Single Market Act in terms of providing a standalone provision for public health). Since the Treaty of Amsterdam and following specific meetings amongst the Council of the Ministers of Health, treaty coverage has included formal legal basis for measures

\footnotetext{
119 Emphasis added. See http://www.who.int/fctc/declarations/en/ [Accessed 1st July, 2016].

120 See Howells, The Tobacco Challenge: Legal Policy and Consumer Protection (Surrey: Ashgate Publishing, 2011). However, most of the literature takes a global perspective, and I have not found any dedicated analyses in this regard examining FCTC and FCTC Guidelines in EU legal system. See for instance, Gostin, Global health law, Cambridge, Massachusetts: Harvard University Press, 2014; and Mitchell \& Voon (eds.), The global tobacco epidemic and the law, Cheltenham, UK: Edward Elgar, 2014, see chapters 3 and 4 specially.

121 See Panel Report, United States - Measures Affecting the Production and Sale of Clove Cigarettes, WTO Doc WT/DS406/R (circulated 2 September 2011, adopted 24 April 2012). Yet, a review of US federal case law reveals some sporadic references to the FCTC, including by a District Court of California on 17th May 2016 in American Beverage Association, Et A1., v. City And County Of San Francisco, Case No. 15-cv-03415-EMC. See also
} 
in the field of public health. ${ }^{122}$ For our purposes, it is of note the "incentive measures" which endure in Article 168(5): "incentive measures... which have as their direct objective the protection of public health regarding tobacco". ${ }^{123}$ What we knew (and still know after the rulings), and possibly Romania knew this all too well, was that Article 168(5) does not interfere with the lead role of Article 114 TFEU: Article 114 is a lawful basis once the Court is able to be satisfied that an internal market approximation measure enacted does in fact contribute to free movement or undistorted competition, for example by addressing current or expected market fragmentation. From that point, it seems merely a matter of academic discussion as to whether Article 168(5) TFEU (or any other legal provision) has a limiting effect because the measures also contribute to public health.

I would also like to add that it is curious and potentially regrettable that given the ambition of the EU as a norm-taker and norm-setter for tobacco regulation norms (see Section 4.6 below), the Lisbon Treaty amendments to Article 168(5) TFEU limited itself to "tobacco" and not therefore extending legislative scope to the emerging range of related products - a welcome innovative feature of the TPD, even if we can understand the lack of competence beyond the already present "incentives measures" and exclusion of harmonisation. Article 168(5) remains a damp squib: vaporous and possibly meaningless in the bigger policy picture. It is worth noting a debate that continues in scholarship of its actual and representative value; It is unclear whether the specific reference to "tobacco" which is rather unique in the treaty, goes beyond something symbolic and actually serves to expand the legal and political legitimacy of the EU. ${ }^{124}$ I would argue that the present treaty wording limits legislation to information and financing schemes as its contribution to meaningful policy reform, precisely those types of 'awareness measures' that the Court and Advocate General regarded as less effective in controlling tobacco consumption. ${ }^{125}$ The Commission too observed in the preadoption process and before the Court, such information campaigns are not capable of removing obstacles to trade which exist on account of divergent national rules (e.g. on the use of characterising flavours ${ }^{126}$ ) in accordance with Article 114 TFEU or of preventing them from arising.

For the purposes of discussion though, is it possible to say that the TPD measures are not measures which have as their direct objective the protection of public health regarding tobacco? Is tobacco control the indirect objective? If we consider the prohibition of menthol cigarettes and the new graphic health warnings covering the majority of the display areas, it would be pedantic to deny that public health, and specifically tobacco control, is the main objective; this might be better

\footnotetext{
122 See http://eur-lex.europa.eu/legal-content/EN/TXT/?uri=URISERV\%3Aa16000 [Accessed 1st July, 2016]. For a thorough historical legal account of public health law in the EU, see Hervey \& McHale (2015) European Union Health Law: Themes and Implications, Cambridge: Cambridge University Press (especially chapters 3 and 15).

${ }^{123}$ Emphasis added. The post-Lisbon amendments also meant that Article 168(5) contains new legal bases in accordance with the ordinary legislative procedure as well as the words "abuse of alcohol". See generally, A6-0013/2008, Report on the Treaty of Lisbon 2007/2286 (INI).

${ }^{124}$ See Gerber, Between a rock and a hard place - the controversial case of legis lative harmonization and national lifestyle policies,' in Alemanno and Garde 2015, chapter 7.

125 See for instance, Philip Morris at paragraph [182]. See also opinion at point [62]), where the Advocate General noted that, "at the time when the Directive was adopted, there was already, in at least two Member States - Belgium and Germany - even a prohibition of certain menthol capsules in cigarettes, with the result that it was not permitted in any case to place this specific variant of menthol cigarettes on the market there".

126 See for instance, Poland opinion at point [123] and Philip Morris opinion at point [174].
} 
presented either as a dual-objective or one of two direct objectives. It might also be hard to find anyone who believed the Advocate General when she repeated on several occasions words to the effect that the TPD is not a public health measure but an internal market harmonisation measure ${ }^{127}$ or even the UK government - who in chorus with the Parliament, Council and Commission explicitly stated, "the aim of Directive 2014/40 is not to protect public health". ${ }^{28}$ Certainly for the cynical observer, this kind of rhetoric reflected half-truths and not merely legal pedantry. Personally, I prefer the Court's version when it stated the TPD should rightly be referred to as having two objectives: "in that it seeks to facilitate the smooth functioning of the internal market for tobacco and related products, while ensuring a high level of protection of human health, especially for young people". ${ }^{129}$ We could even reformulate this version, thus: ensuring a high level of protection of human health, especially for young people, while seeking to facilitate the smooth functioning of the internal market for tobacco and related products. ${ }^{130}$ Howsoever couched, it is clear that this duality of objectives does not equate to parity. The lack of equal weighting between the public health objective and the market-building/-smoothening objective may serve to strengthen the argument that health is the main concern.

Looking at the opinions something more interesting was revealed. In examining "proportionality in the strict sense", Advocate General Kokott referred repeatedly to "the value system under EU law". She described this "value system" as if it were a given or well-established reference point in EU law, also that it was an understood conclusion that health had "considerably greater importance" in the system of common yet competing values, i.e. vis-à-vis economic or market interests - and this conclusion emerged as well in the passages dealing with the EU Charter. ${ }^{131}$ Initially, it was unclear whether this meant a "value system" in regard to the TPD and its competing set of interests or in general, or both, because both contexts are used. ${ }^{132}$

An argument for the narrower TPD context is found by looking once more to the FCTC for explanation. Although not referred to in this way, there are parallels in the view of public health as of "considerably greater importance" within the FCTC's set of norms (= "value system"). The most unconcealed illustration of which is found in the wording of the guidelines attendant to the FCTC's 'General obligations', where it explicitly refers to "a fundamental and irreconcilable conflict between the tobacco industry's interests and public health policy interests". ${ }^{133}$ Such an approach may be a

\footnotetext{
127 See Philip Morris opinion at point [123].

128 See Poland at paragraph [108].

${ }^{129}$ See Poland at paragraph [116].

${ }^{130}$ In my opinion, this reformulation is much more accurate that where in each of the openings to the three opinions, the Advocate General stated: "what latitude does the Union legislature still have in ensuring that products may be placed on the market under uniform conditions throughout the European Union without losing sight of the fundamental objective of a high level of health protection, which has been enshrined prominently in primary law (Articles 9 TFEU, 114(3) TFEU and 168(1) TFEU and the second sentence of Article 35 of the Charter of Fundamental Rights of the European Union)?" See for instance, Philip Morris opinion at point [4].

${ }^{131}$ See for instance, Poland opinion at point [130] and Pillbox opinion at points [130] and [190].

132 See for instance, Philip Morris opinion at points [179] and [193] respectively.

${ }^{133}$ Emphasis added. See Article 5.3 FCTC reads: "In setting and implementing their public health policies with respect to tobacco control, Parties shall act to protect these policies from commercial and other vested interests of the tobacco industry in accordance with national law."
} 
contributory factor to any subsequent lack of rigour in reasoning and analysis, precisely because by its nature, the TPD implements the FCTC (and its "value system") and will inevitably adopt the same sets of values (which it clearly does). On this view, it could be argued that the ends justify the means with the EU seen as norm taker. That may well be satisfactory as an outcome, but one would expect that in open court whether the new public health laws in fact strike a "fair balance" is properly assessed and not assumed.

To its credit, the Second Chamber was noticeably less binary in its public approach. The Court confined itself to well-established legal arguments and it should be credited in that it did not seek (or resisted the temptation) to reduce matters to "the very basic problem underlying the legal questions" as presented by the politically less constrained Advocate General. ${ }^{134}$ And in fact, the Court makes no mention at all of so-called "the value system under EU law". We can though assume that from the Court's view that the need for determining a "fair balance" as applied to and within the TPD suggests that any such ordering of values to be done is after all specific to the case and policy at hand. This view is supported when the Court acknowledged that the EU legislature's discretion varied for each of the goals justifying restrictions on EU Charter freedoms and depends on the nature of the activities in question. ${ }^{135}$

\subsection{Proportionality and Fundamental Rights}

Before the EU Charter's elevation as a primary source of EU law, ${ }^{136}$ the CJEU in this field had generally based its interpretations on the case law of the ECtHR and the constitutional traditions of the EU Member States. ${ }^{137}$ Hence the EU Charter requires that for equivalent rights (between EU Charter and ECHR) "the meaning and scope of those rights shall be the same as those laid down" by the ECHR. ${ }^{138}$ Apart from this, these well-established practices would inform the development of jurisprudence for the EU Charter and a judicial methodology stressing a need to reconcile 'competing' fundamental rights. ${ }^{139}$ In research published before the TPD rulings but compiled on the basis of the Commission's initial proposal to the TPD, I urged the Court to produce an analysis of the interplay

\footnotetext{
134 “A very basic problem ultimately underlies these legal questions, which involve huge economic interests and affect the lives of millions of Union citizens every day: what latitude does the Union legislature still have in ensuring that products may be placed on the market under uniform conditions throughout the European Union without losing sight of the fundamental objective of a high level of health protection, which has been enshrined prominently in primary law (Articles 9 TFEU, 114(3) TFEU and 168(1) TFEU and the second sentence of Article 35 of the Charter of Fundamental Rights of the European Union)?" This passage is found verbatim amongst the opening points in each opinion.

135 See Philip Morris at paragraph [155].

136 'The Union recognises the rights, freedoms and principles set out in the Charter of Fundamental Rights of the European Union of 7 December 2000, as adapted at Strasbourg, on 12 December 2007, which shall have the same legal value as the Treaties.' (Article 6(1) (TEU) (consolidated version) March 2010).

137 See in this regard, Kühling, 'Fundamental Rights' in von Bogdandy and Bast (eds), Principles of European Constitutional Law (Hart Publishing, Oxford 2010) 479-514, at 481.

138 See first sentence of Article 52(3) EU Charter. Note that in the EU Charter the health provisions (Article 35) sit outside the freedom of expression provisions (Article 11), in contrast to ECHR (Article 10(2)).

139 See, in this regard, Case C-544/10 Deutsches Weintor [2012] at [47]: 'It follows from this that such an assessment must be carried out in accordance with the need to reconcile the requirements of the protection of those various fundamental rights protected by the Union legal order, and striking a fair balance between them (see, to that effect, Case275/06 Promusicae [2008] ECR I-271, paras 65 and 66).'
} 
between right to expression and right to health. ${ }^{140}$ And I agreed with EU constitutional scholars that it was vital the CJEU develop its own jurisprudence and own version of the ECHR-equivalent provisions that whilst faithful to the ECHR and ECtHR they are EU-specific. All the more so as the CJEU continues to transform itself into some form of a fundamental rights court and is able to assess the suitability of "Union law providing more extensive protection", ${ }^{141}$ such as for a right to health or the freedom of expression, and thus "applying the Charter directly rather than as a mere source of inspiration". ${ }^{142}$ I further argued that the Court was well placed, if not best placed, to draw on its experience in EU tobacco policy (and related areas, such as EU trade mark law, free movement, etc.) in clarifying the impact of the EU Charter as regards the judicial review of the TPD. In particular, I was looking for clarity regarding Article $35 \mathrm{EU}$ Charter; specifically, the relative importance of the right to expression in the context of the right to health, the analysis of which is implied from the discussion of Articles 11 and 35 EU Charter and from the inclusion of these as part of the proportionality test in the disputes.

One of the biggest disappointments of the rulings was that when called upon to make that determination of a "fair balance" the Court demonstrably failed to give a meaningful or analytical account as to the relative importance of freedom of expression (compared to all fundamental rights), and in its relative clout compared with health. In Poland and Philip Morris, the Court swiftly rejected the submission that the TPD had "affected" the "essence" of the EU Charter rights at issues (i.e. expression in Article 11, property in Article 17) even though the Court had already accepted that the right had in fact been "interfered with". ${ }^{143}$ We already knew that Article 52 EU Charter includes the requirement that the essence of a fundamental right be respected. The explanation offered by the Court for its position was that the prohibition of "certain elements and features" did not affect the essence of the Article 11 freedom but merely controlled them in a clearly defined way. ${ }^{144}$ Not only was this apparently hurried, it was confusing. For national courts, it may be difficult to extract much from these brief statements. Mr Justice Green observed in BAT that the Court had not adequately explained how a fundamental right could be interfered with yet not even affected, as in the case of freedom of expression. The reasoning is muddled, but the message appears to be: A fundamentalright is not impaired or even affected just because another public interest right trumps it (we might want to qualify this to applying within the TPD (public health and tobacco) context). the English judge went on: "It will be evident to any reader of the [Philip Morris] judgment that the evaluation of the components of the proportionality test is very cursory and in many instances conclusionary." "145

\footnotetext{
${ }^{140}$ See Els more, Trademarks, Tobacco, Health - Brokerage by Fundamental Rights? Chapter 3 in Alemanno \& Bonadio (eds.) The New Intellectual Property of Health - Beyond Plain Packaging (September 2016), Edward Elgar.

${ }^{141}$ See second sentence of Article 52.3 EU Charter.

142 See in this regard, Landenburger, 'Session on Protection of Fundamental Rights post-Lisbon: the Interaction between the Charter of Fundamental Rights, the European Convention of Human Rights and National Constitutions' in Laffrange (ed.), The Protection of Fundamental Rights Post-Lisbon, Reports of the XXV Fide Congress, and Kühling, 'Fundamental Rights' in von Bogdandy and Bast (eds), Principles of European Constitutional Law (Hart Publishing, Oxford 2010) 479514, 481.

${ }^{143}$ See for instance, Philip Morris at paragraphs [151] and [148].

144 See Philip Morris at paragraph [151].

145 See BAT at paragraph at [255].
} 
It is difficult to rationalise the Court's approach. It would have been fully aware - in light of the opinions - of the dearth of CJEU case law on Article 11 and Article 35 EU Charter. We might have expected the Court to allocate some attention to this matter. Agreeably, little has been discussed - in judicial or academic settings - of the right to health generally, and under the EU Charter, and next to nothing regarding the interplay with expression. ${ }^{146}$ Though again, this may necessitate rather than obviate the need for some guidance. Article 35 is mentioned throughout the disputes. Article 35 EU Charter, titled 'Health care', reads in full: 'Everyone has the right of access to preventive health care and the right to benefit from medical treatment under the conditions established by national laws and practices. A high level of human health protection shall be ensured in the definition and implementation of all the Union's policies and activities." Only the emphasised second sentence was relevant.

Initially, it was apparent from the wording how the Charter through Article 35 on "human health" is more individually formulated than the equivalent reference to "public health" in TFEU and FCTC. ${ }^{147}$ This might be expected from a document on fundamental rights. Article 35 was presented both in the human and public setting, and presented to and by the Court as a fundamental objective of the EU: an interest and right which the Court subsequently deemed was superior to other conflicting rights, and the "addictive effects" of tobacco and its impact upon children who, because of addiction, were to be treated a "particularly vulnerable class of consumers", warranted that public health acts as a guiding principle. What we can gather is that by upholding the contested provisions of the TPD, including outright bans of certain products, the Court has if not explicitly then implicitly endorsed the "value system" directly presented by the Advocate General. Firstly, as seen in Pillbox, the Court did indicate that instances involving public health rank "foremost" in the list of interests which may justify impediments to free trade and other fundamental principles. ${ }^{148}$ Secondly, the cumulative result of the rulings was that "the right to health" trumps the competing fundamental values claimed, namely the right to express themselves or to provide information in relation to that business and the right of persons to conduct business; a process that confirms - as Mr Justice Green observed - "the absolute primacy of the right to health". Thirdly, was the confirmation of the status of Article 35 as a statement of a general policy position, which is already stated in the TFEU, i.e. that a high level of health protection must feature (see Articles 9 TFEU, 114(3) TFEU and 168(1) TFEU, which are all repeatedly cited in the judgments).

\footnotetext{
146 None of the five CJEU actions I found at time of writing on Article 35 EU Charter had previously involved Article 11, on which I found nine actions. See the EU Agency for Fundamental Rights online resources at www.fra.europa.eu/en/case-law-database/field info charter article\%253Asource/13518 [Accessed 1st July, 2016]. The five cases comprise one Decision, three Opinions and one Order. The latter involved tobacco products, though the facts involve only customs and taxation matters pertaining to the selling of cigarettes by two members of the Belgian army. See Case C-267-268/10 André Rossius and Marc Collardv Belgium [2011].

147 There is some inconsistency of terminology in the judgments, notably in the Court's interchangeable use of "public" and "human" as regards health. This may stem from the same interchange adopted in the TFEU (and less so the WHO/FCTC), compared for instance, to the EU Charter which refers only to "human health" in Article 35. Although the ECHR refers only to "protection of health" it does in the context "of others", as in Article 10 on freedom of expression. 148 See for example: Case C-473/98 Kemikalieinspektionen v Toolex Alpha AB [2000] ECR I 5702 at paragraph [38] (which concerned the outright prohibition on the industrial use of a particular chemical).
} 
Perhaps the overriding difficulty of this analysis, and explanation for the lack of it in open court, was the prospect that health under Article $35 \mathrm{EU}$ Charter could not be properly treated as a hard-core right (unlike freedom of expression). On this point, a lawyer for the Commission involved in the genesis of the Charter and Article 6(1) TEU was tentative as to the status of the Charter's 'right' to health regarding it "as probably a 'mere' principle". ${ }^{149}$ While 'right to health' is protected by the EU legal order, less discernible is "what this right entails and how it can be operationalized to promote healthier lifestyles and thus contribute to the prevention and control of NCDs [non-communicable diseases] in Europe'. ${ }^{150}$

It is the lack of attention paid by the Court to the interplay of fundamental rights, despite the conclusions reached, was which most worrying and appears to suggest a nervous judiciary. Although in Philip Morris the Court does refer on three occasions to its recent decision in Neptune concerning lawfulness of public health claims on products (which in turn followed established ECHR case law), and was used to support the view that freedom of expression must be held to cover the use by a business, on the packaging and labelling of tobacco products, of indications such as those covered by Article 13(1) TPD. ${ }^{151}$ Neptune did concern health claims but that the Court did not in fact address Article 35 (the opinion briefly did) though it did tackle Article 11 EU Charter in the context of a prohibition of the claim 'very low in sodium/salt' and any claim likely to have the same meaning for the consumer used as regards natural mineral waters and other waters (which the Court upheld). Neptune was therefore of limited value.

In general and rather vague terms, the Court found that larger picture warnings on tobacco packaging would be more likely to retain their effectiveness over time and would be particularly effective in communicating health effects to low-literacy populations, children and young people, and this interest outweighed any rights connected to freedom of expression. ${ }^{152}$ This is seemingly at odds with jurisdictions where freedom of expression is jealously protected, and actual and threatened litigation based on such rights have had a stalling effect on health policy, in particular tobacco reform. ${ }^{153}$ The EU Charter rights connected to freedom of expression were not elaborated and the analytical account is conspicuous compared to equivalent discussions of Article 10 ECHR at the ECtHR (upon which Article 11 EU Charter was based), and noticeable is that the freedom of expression discussion (for what it was) focussed on "a business's freedom of expression and

\footnotetext{
${ }^{149}$ See Landenburger, 'Session on Protection of Fundamental Rights post-Lisbon: the Interaction between the Charter of Fundamental Rights, the European Convention of Human Rights and National Constitutions' in Laffrange (ed.), The Protection of Fundamental Rights Post-Lisbon, Reports of the XXV Fide Congress, Tallinn (2012) at www.fide2012.eu/index.php?doc id=88 [Accessed 1st July, 2016].

${ }^{150}$ See Alemanno \& Garde, Regulating Lifestyles in Europe: How to Prevent and Control Non-Communicable Diseases Associated with Tobacco, Alcohol and Unhealthy Diets? (Swedish Institute for European Policy Studies, Stockholm 2013) 7 , at 47.

151 See Philip Morris at paragraph [147], citing C-157/14 Neptune Distribution (EU:C:2015:823), paragraphs [64] and [65].

152 See Philip Morris at paragraphs [61], [144], [152], [156], [170], [176], [197] and [204].

153 See Kelsey, J, 'International Trade Law and Tobacco Control: Trade and Investment Law Issues Relating to Proposed Tobacco Control policies' (2012), at www.turanga.org.nz/node/41 [Accessed 1st July, 2016]; and Cameron, J, 'Cigarette Packages, Tobacco Consumption and the Charter: The Role of Perception and Harm in Charter Analysis' in JC Luik (ed.), Plain Packaging and the Marketing ofCigarettes (Admap Publications, Abingdon 1998) 135-57.
} 
information" with little attention paid to the right to receive information on the part of the public, consumers generally, and brand loyal customers of tobacco and related products, more generally a part of the established ECtHR and CJEU case law and European-based scholarship (concerning Article 10 ECHR) including for 'commercial communications'. ${ }^{154}$ As I have argued elsewhere, while none of the warnings and images on tobacco products could be classified as patently false, they certainly do not impart purely factual, accurate or uncontroversial information to consumers, ${ }^{155}$ and it could be suggested that they may even be misleading in certain respects. ${ }^{156}$ Unfortunately there is little account from the Court as to the informational value (vis-à-vis the buying European public) of the new packaging measures, a matter which has attracted sceptical judicial analysis in US case law. ${ }^{157}$ Could it be the Court was thinking that EEA parliaments will to varying levels implement the TPD reflecting Article 24(2) and national traditions for protecting expression, including commercial expression, which can vary considerably, will come into play? ${ }^{158}$

Instead of the CJEU clarification and insight I had hoped for there was abbreviated passages that cursorily concluded human health protection "outweighs the interests put forward by the

${ }^{154}$ For CJEU rulings: see Case C-71/02 Herbert Karner Industie Auktionen GmbH and Troostnyk GmbH [2004] 2 CMLR 5 and Case C-376/98 Germany v Parliament and Council [2000] ECR I-8419. For ECtHR: see notably Markt Intern Verlag GmbH and Klaus Beermann v Germany (1989) 12 EHRR 161; other cases include Barthold v Germany (1985) 7 EHRR 383, Casado Coca v Spain (1994) 18 EHRR 1, Demuth v Switzerland (2004) 38 EHRR 20, Hertel v Switzerland (1998) 28 EHRR 534, Jacubowski v Germany (1994) 19 EHRR 64, Stambuk v Germany (2003) 37 EHRR 42. For EU relevant discussions, see Krzeminska-Vamvaka, Freedom of Commercial Speech in Europe (Verlag Dr Kovac, Hamburg 2008); Shiner, Freedom of Commercial Expression (Oxford University Press, Oxford 2003); Munro, 'The Value of Commercial Speech' (2003) 62(1) Cambridge Law Journal 134-58; and Barendt, E, Freedom of Speech, 2nd edn (Oxford University Press, Oxford 2005) chapter xi; and Cram, I, Contested Words: Legal Restrictions on Freedom of Speech in Liberal Democracies (Ashgate, Aldershot 2006), especially chapter 7.

155 See Elsmore, Trademarks, Tobacco, Health - Brokerage by Fundamental Rights? (n XX above).

156 See Elsmore, Law and Legitimacy (n XX above), with regard to the removal of TNCO information, and misleading use of the 'Smoking causes 9 out of 10 lung cancers' warning. See for supportive and conflicting arguments in this latter regard, Barton, 'How Tobacco Health Warnings Can Foster Autonomy', Public Health Ethics, Vol. 6, 2013, pp. 207-219 and Hammond 'Health Warning Messages on Tobacco Products: A Review', Tobacco Control, Vol. 20, 2011, pp. 327337 (respectively).

157 In 2012, a US Federal Court preferred not to characterise similar measures to the TPD's standardisation measures as 'information', stating instead that: 'They are unabashed attempts to provoke emotions (and perhaps embarrassment) and browbeat consumers into quitting. See $R J$ Reynolds Tobacco Co v Food and Drug Admin nos 11-5332, 12-5063 696 F3d 1205, 1217 (2012). For case comment, see 'R J Reynolds Tobacco Co v. Food and Drug Administration: DC Circuit Holds that FDA Rule Mandating Graphic Warning Images on Cigarette Packaging and Advertisements Violates First Amendment' (2013) 126 Harvard Law Review 818.

158 Some European countries are more tentative on their prima facie protection of commercial expression than most (as was the case for Australia in the JT International case, see n XX above). In Norway, it is generally understood that freedom of expression does not cover advertising, and Dutch nationaldecisions have found that advertising is not covered by the constitutional provision for freedom of expression. Other countries include France, Germany and Switzerland. See Verpeaux, Freedom of Expression in Constitutional and International Case Law (Council of Europe Publishing, Strasbourg 2010) 164-169. An account of the national picture can be gathered from Brüggemeier (ed.), Fundamental Rights and Private Law in the European Union (Cambridge University Press, Cambridge 2010). See also Randall, 'Human Rights within a Multilayered Constitution: the Example of Freedom of Expression and the WTO' in Max Planck Yearbook of United Nations Law (Brill, Leiden 2012) 183-280. 
claimants". ${ }^{159}$ The extent of the Court's "analysis" or lack of it was such that Mr Justice Green felt minded to caveat the limited usefulness of parts of the Court's analysis including proportionality assessment to the $B A T$ case. There is scant guidance from the Court on this occasion as to how exactly to tackle the proportionality test, especially when detailed evidenced can be presented at national proceedings, and as has been seen in other related Court rulings and the English BAT case. ${ }^{160}$ Whilst it ought to be noted that I had anticipated a Grand Chamber to hear all or one of the judicial reviews (notably regarding standardisation measures), I regarded such an analytical exercise as a way to buttress what I had called "an impression of lip service to fundamental rights in equating IP and health" by the Commission that had been in my view "possibly obscured by a contemporary and globalizing policy" for tobacco control emanating from the WHO's FCTC (as well as what had happened in Australia, including the successful defence of the TPPA 2011). ${ }^{161}$ Sadly, this remains. I understand the strategic reasons for using the same Second Chamber Court for all three rulings, in some areas, notably in Philip Morris, a 13-strong judicial panel might have been more suited to discharge the clarification and guidance role assigned to the CJEU on the interpretation of the Treaties and equivalent sources, such as the EU Charter. One can also hope that in the not too distance future the confused discussion about the "essence" and "interference" of fundamental rights also comes to be clarified, and that in future it will be clearer whether the fundamental rights assessments are meant to be part of the proportionality test or a discrete appraisal in itself: the Court seemed to vary in its approach; in Pillbox it indicated that Article 52 EU Charter included matters that had to be implemented or applied within the test of proportionality, but the same approach was not adopted in the other rulings.

\subsection{Counterweighing Observations}

With all this said, we should include some contextual comments. Firstly, and most obviously, in Pillbox and Philip Morris the Court cannot of course decide the case; even if it had wanted to attempt to apply its own interpretation, the paucity of detailed evidence that the parties placed before the Court is a limiting factor; as noted by the judges' extended discussions of admissibility of the questions and claims, especially by the Advocate General. ${ }^{162}$

Secondly, there are complicating factors. The very nature of tobacco control is such that it is not about isolated policies or single, temporary or one-off solutions, rather a wide range of overlapping national, regional and global measures including advertising restrictions, display bans and smoke-free environments. As stressed by the Court and at length by the Advocate General, Article 114 TFEU precisely enables different types of harmonisation and legislative action in inclusion of

\footnotetext{
159 See Philip Morris at paragraph [156].

160 See Case C-333/14 Scotch Whisky Association et Ors v Lord Advocate, Advocate General for Scotland (23rd December 2015) concerning a measure of a Member State in relation to the nexus between tax and minimum price measures for alcohol.

161 See Elsmore and Obolevich (n 16 above). It ought to be noted that the Australian constitutional law framework does not expressly protect freedom of speech (that is, expression) and freedom of expression was not a consideration for the TPPA, which is seen in the way the High Court of Australia, in reviewing the constitutional muster of TPPA, made no reference to speech as part of its analysis (nor did the applicant for judicial review). See note 81 above, noting the decision in JT International SA. See also p. 51 (xxxi) of the Australian Constitution.

162 See for instance, Kokott's detailed and clearly agitated considerations in Philip Morris opinion at point [12]-[52].
} 
the words 'measures for the approximation'. Hence, measuring any given tobacco control measure or piece of legislation would always be fraught with uncertainty. Hence a significant issue in these disputes (and which runs through tobacco policy evaluation generally) and especially seen in Philip Morris, are the methodological challenges to the actual measurement of policy effectiveness: whilst the EU legislator hopes to reduce by 2 percentage points the European demand for tobacco products over the next 5 years notably through standardisation measures, the real value to be achieved will be unmeasurable, i.e. the extent to which it puts off current non-smokers, that is to say young people who presently do not smoke. Besides, the fact that due to the combined effect of the several and existing anti-smoking measures, general rates of smoking uptake, prevalence and use are declining anyway also presents difficulties. ${ }^{163}$

Thirdly, there is the challenge of evidence - the focus and strength of which is constantly changing - and to ensure the pursuit of evidence-based policy (rather than policy-based evidence). Let us consider briefly that the European public will be presented with shocking images on tobacco products. The imagery could literally be a look for European consumers of things to come on the packaging of unhealthy foods and beverages, as well as 'tobacco-related' products. Whether these interim measures "work" or not - from an empirical standpoint regarding for tobacco demand and smoking prevalence - is not the most essential issue, as courts and judges will review what evidence existed beforehand and will not be comfortable to demand of the respondent legislator the burden of showing that the measures will or do work, as shown by Mr Justice Green's analysis in BAT. The legal and political context in this complex field makes it highly unlikely the CJEU would ever find adopted EU measures (already in place elsewhere) invalid and disproportionate. This reading might also explain a subtext for the proportionality examination (or lack of it) by the Court, including for fundamental rights. In any case, measurement requires valid and non-conflicting data. Let us consider for example, that in 2014 the Royal College of Physicians Tobacco Advisory Group said: "It is important that policies continue to be developed, improved and innovated to retain initiative and impact with smokers and the general public. It is also important to consider that the individual components of tobacco control policy typically have modest effects. It is their collective impact in the context of a comprehensive range of policies that becomes substantial."164 In 2016, that same British scientific community recommended that e-cigarettes should be promoted at policy level because they are likely to be beneficial to UK public health; "smokers can therefore be reassured and encouraged to use them, and the public can be reassured that e-cigarettes are much safer than smoking." 65 Perceived mixed scientific messages and a discrepancy of expert views as applied to the regulation of tobacco and related products presents insurmountable challenges for any chamber of

\footnotetext{
163 The FCTC creates obligations to meet the treaty objective to reduce continually and substantially the prevalence of tobacco use and exposure to tobacco smoke through the implementation of "comprehensive tobacco control strategies". ${ }^{164}$ See 'The report of the independent review into standardised packaging of tobacco', by Sir Cyril Chantler, 3 April 2014 (point 6.1): $\quad$ http://webarchive.nationalarchives.gov.uk/20140911094224/http:/www.kcl.ac.uk/health/packagingreview.aspx [Accessed 1st July, 2016].

165 In their report dated 27 April 2016, the Royal College of Physicians Tobacco Advisory Group concluded that "On the bas is of available evidence, the RCP believes that e-cigarettes could lead to significant falls in the prevalence of smoking in the UK, prevent many deaths and episodes of serious illness, and help to reduce the social inequalities in health that tobacco smoking currently exacerbates." See https://www.rcplondon.ac.uk/news/promote-e-cigarettes-widely-substitutesmoking-says-new-rcp-report [Accessed 1st July, 2016].
} 
the Court of Justice. It is national judges that must make such assessments, as seen in BAT. ${ }^{166}$ From the EU law and CJEU point of view, where it is established there are uncertainties in the state of scientific knowledge of a given area of law and policy, this serves to broaden the margin of appreciation enjoyed by the State and this is especially the case in the area of public health and makes it sensible to adopt a precautionary approach - as the Court has once again done. ${ }^{167}$

Lastly, it is accepted that the actual intensity of review may be variable and may depend upon the margin of appreciation to be accorded to the Union legislature, notably the Commission, i.e. DG SANCO in this case as the proposers of the legislation. Hence, there is a difference between a review of EU legislation and national legislation and the UK Supreme Court has stated - in the setting as well of partially harmonised EU health measures - that the test for proportionality at the EU level of EU legislation was less strict than that applied at the national level. ${ }^{168}$

\subsection{Paternalism by Persuasion and 'De-normalisation': Leading the Pack?}

It is apparent how the FCTC has been an inspiration for the EU. In two important respects however, the Union legislature has arguably acted beyond norm-taker as a 'norm-setter'. ${ }^{169}$ This could be seen in regard to the TPD's substantive scope as from the discussions concerning tobacco related products reveal, i.e. that EU law now extends to e-cigarettes and refill containers; this observation may even apply to the EEA-wide menthol ban although that was more about matters of regulatory degree as opposed to product markets previously unregulated.

More explicit and more symbolic in the wider 'EU lifestyle policy' context has been the regulatory emphasis of the Union legislature in placing "young people" as a central reference point. It was initially unclear how this EU-TPD emphasis correlates to the FCTC which conspicuously lacks any kind of emphasis in regard to young people or youth. We know at least this focus is a clear innovation of the new TPD compared with the previous TPD. As an intended beneficiary of the TPD in general, and specifically the standardisation measures applying to packaging and labelling and graphic health warnings, "young people" was stressed time and again throughout the Court's judgments. ${ }^{170}$ Additionally, not all the regulatory techniques included in the TPD apply to all products; thus cigars, cigarillos and pipe tobacco are generally outside the scope because such products are predominantly used by, and perceived as connected with, old or older people. ${ }^{171}$

For such a norm-setter account to be persuasive - and somehow add to the "global trendsetter" status given to the FCTC by the WHO itself - we would need to bear in mind that certain

\footnotetext{
166 The very long judgment reflects that the challenge the process by which the UK Parliament came to adopt the legislation, which involved collection and presentation of a huge amount of evidence, was addressed at considerable length by Mr Justice Green - who spoke of the "immense detail of these challenges".

167 See, in this regard, Case 174/82 Sandoz [1983] ECR 2445; Case 174/84 Commission v Federal Republic of Germany [1987] ECR 1262.

168 See R (on the application of Lumsdon) v Legal Services Board [2015] UKSC 41.

169 See Wu, EU's Participation in the WHO and FCTC: A Good Case for 'EU as a Global Actor?' (2010) Asian Journal of WTO and International Health Law and Policy, 5(2): 467-496.

${ }^{170}$ See for instance, Philip Morris at paragraphs [61], [144], [152], [156], [170], [176], [197] and [204].

171 See for instance, Article 11(1) TPD exempting (at Member States' discretion) packag ing of products other than cigarettes, roll-your-own tobacco and waterpipe tobacco from mandatory labelling requirements and combined health warnings.
} 
national legislation already carries such paternalistic emphasis. ${ }^{172}$ Additionally, we would need to confront that the role and focus of young people in the TPD approved by the Court was at odds with other parts of the reasoning. The Court stated in Poland for instance, that it is not appropriate to assess the attractiveness of the product (and hence the product prohibition) by reference to a single group, i.e. young people; whereas in Pillbox and Philip Morris, it was precisely the position and vulnerability of that single group (of young people and even children) that justified the finding of proportionality of the contested measures. ${ }^{173}$ Likewise, the presence of different objective characteristics of ecigarette and refill container products from those of other tobacco products was crucial in Pillbox; whereas it was the similarity of objective characteristics from those of tobacco products to have persuasive effect for the Court in Poland. ${ }^{174}$ While it is prudent not to take out of context such interpretive approaches across lengthy and separated judgments, one could be forgiven for the sense of a missed opportunity to clarify matters (as with Article 168(5) TFEU) amid a slightly muddled approach delivered on the same day by the same personnel by the same Second Chamber Court.

The comment above on youth is more than a passing one. The FCTC-led provisions on labelling and packaging, and Article 24(2) TPD specifically, were at the heart of Philip Morris and subsequently BAT. And tries to communicate - literally - with young people. In the latter case, the English High Court initially noted that "in very simplified terms" one of the theories advanced by the tobacco industry against the UK Regulations 2015 was that standardised packaging would by its very nature wipe out the attractiveness of branding, and that as such "all tobacco packaging and products will become uniformly drab." 175 And yet this is, precisely in simple terms, what the new UK law and TPD was trying to achieve in meeting the FCTC and its guidelines. In so doing, going even further than the suggested recommendations and heading firmly in the direction of Australian TPPA 2011. This is a matter of deduction when we consider that the FCTC has begun from a rather trite point of departure: Tobacco products are commonly made to be attractive in order to encourage their use. This is verbatim wording and affords a broad latitude for tobacco control measures. One view is that tobacco is thus no different a product to be regulated than any other - assuming we can agree in principle that firstly, it would be a strange (tobacco) company that did not seek to promote its wares, assuming the product was lawful, and secondly, that in effect the many different forms of product regulation all serve to shrink the sector under reform, by for example increasing the compliance obligations for businesses and/or the protective rights for consumers.

Yet this reading is misleading. In reality, the Court and Union legislature have acknowledged that tobacco products are not in any sense "ordinary". In the interests of public health, the new EU laws are exactly trying to 'de-normalise': that is to say the manner in which smoking, smokers and the tobacco industry have been routinely depicted in everyday discourse and media representations in a variety of overwhelmingly negative ways, resulting in a severe erosion of "smoking-positive

\footnotetext{
172 TPD - as also in the Australian TPPA 2011 (and to an extent seen in the UK Regulations 2015 which mentions children in the explanatory notes). As well as implementing the TPD, the UK Regulations 2015 implement Sections 94 and 135(2) -

(3) of the Children and Families Act 2014.

${ }^{173}$ See, respectively, Poland at paragraph [130], Pillbox at paragraph [130] and Philip Morris at paragraph [190].

174 See, respectively, Poland at paragraph [130] and Pillbox at paragraph [130].

175 See $B A T$ at paragraph [32].
} 
cultures" and tobacco and smoking as "normal", ${ }^{176}$ derived from sociological research into the concept of human 'stigma'. ${ }^{177}$ In this regard, the comprehensive range of tobacco control policies ought to be in mind. The collective aim of 'de-normalisation' among society of tobacco as a product and particularly smoking as a lifestyle and behaviour - through the use of standardising the unattractive and unordinary aspects of the underlying product - is aimed squarely at youth, i.e. the untapped mass of yet-to-be smokers. Whilst one might hope that every adult in Europe by now knows the potential deleterious impacts of smoking, youth consumers may not only be unclear or careless as to this fact, they may not realise that most long-term smokers start smoking young (between 1824 years old) and that as human beings we tend to prioritise the benefits of present behaviour at the expense of future costs, known as 'psychological discounting'. ${ }^{178}$

The 'making tobacco less attractive' goal is an example of (EU) 'nudge' policy, ${ }^{179}$ 'soft paternalism', ${ }^{180}$ or what I refer to as 'paternalism by persuasion', and must be seen in the comprehensive range of policies - and not just those examined under the TPD. This regulatory template ought also to be seen in the context of a discussion emerging amongst scholars as to the emergence of an 'EU lifestyle policy', i.e. one that collects a range of NCDs including tobacco consumption, alcohol abuse and unhealthy diet, which in behavioural terms remain rooted in a complex interplay of agent, host and environmental setting including regulation and (de)normalisation. ${ }^{181}$ From a theoretical perspective these policies are challenged by overlapping

\footnotetext{
176 See Chapman, Markers of the denormalisation of smoking and the tobacco industry, Tob Control 2008; $17: 25-31$.

177 See Chapman, n XX above, indicating as other authors have done that the sociological analysis of stigma and its resultant "spoiled identity" by Goffman in the 1960s was consonant with how in modern societies the meaning of smoking has changed with widespread tobacco control (notwithstanding that Goffman did not list smoking as a stigmatised behaviour but did list "blemishes of individual character" that included addiction and alcoholism; this is hardly surpris ing given the widespread behaviour of smoking in post-war America at that point). See, in this regard, Goffman E. 'Stigma: notes on the management of spoiled identity'. Harmondsworth: Penguin, 1990.

178 There is a wealth of literature in this field, also applying to the 'endowment effect', which would apply the discount approach to current smokers reluctant to give up the loss (of smoking) under the status quo for the prospect of ceteris paribus an unknown future gain, e.g. better health. On some of the theories behind these points, see John et al. (eds.), Nudge, Nudge, Think, Think: Experimenting with Ways to Change Civic Behaviour, Bloomsbury Academic Publishing, 2011. For more specific technical analyses, see Daniel Kahneman and Amos Tversky, 'Prospect theory: An analysis of decisions under risk', Econometrica, Vol. 47, 1979, pp. 313-327; Shane Frederick et al., 'Time discounting and time preference: A critical review', Journal of Economic Literature, Vol. 40, 2002, pp. 351-401; and William Samuelson and Richard Zeckhauser, 'Status Quo Bias in Decision Making', Journal of Risk and Uncertainty, Vol. 1, 1988, 7-59. For a philosophical overview, see Lee Anne Fennell, 'Willpower and Legal Policy', Annual Review of Law and Social Science, Vol. 5, 2009, pp. 91-113. For an application of these theoretical views to the types of measures in the TPD, see Elsmore, Law and Legitimacy ( $\mathrm{XX}$ above).

179 See Thaler and Sunstein, 'Nudge: Improving Decisions About Health, Wealth, and Happiness' (New Haven: Yale University Press, 2008), and Sunstein and Thaler 'Libertarian paternalism is not an oxymoron' (2003) 70 University of Chicago Law Review 1159.

${ }^{180}$ See in this regard, Elsmore n XX above. See also Ogus, 'The paradoxes of legal paternalism and how to resolve them' Legal Studies, Vol. 30 No. 1, March 2010, 61-73, and Dworkin 'Moral paternalism' (2005) 24 Law and Philosophy 305. ${ }^{181}$ See, in this regard, see Alemanno and Garde n XX above. For a non-EU discussion, see Arcuri, InternationalEconomic Law Meets Lifestyle Risks: What Role for International Standards? Eu ropean Journal of Risk Regulation (2013) $4,542$. For a FCTC inspired discussion, see Lien and DeLand, Translating the WHO Framework Convention on Tobacco Control (FCTC): Can we use tobacco control as a model for other non-communicable disease control? Public Health, 2011.
} 
behavioural characteristics; namely joined choice, including legislature, industry and consumer, which implies NCDs are preventable. Paternalism by persuasion is clever. It not only preserves individual 'choice' of(young) adult consumers (which in the tobacco and smoking setting has already been increasingly limited by policy parameters), it simultaneously avoids a series of fiscally and politically unpalatable questions such as whether to ban tobacco and smoking altogether as some nation states like Norway and New Zealand are contemplating.

\section{Conclusion}

The month of May in 2016 was full of activity in the field of tobacco law and policy in Europe. Fittingly enough, 31st May 2016 was the twentieth occasion of the WHO-inspired 'World No Tobacco Day' and on that day the UK's Public Health Minister (closely connected with the UK Regulations 2015) was duly honoured on these occasions - following the same award in 2014 for the European Commissioner for Health in charge at the time of adoption of the TPD. ${ }^{182}$ Fortunately, there are more substantial things for legal scholars to ponder in light of Poland, Pillbox and Philip Morris on the latest EU directive for tobacco and related products. The Court rulings may mark some kind of watershed moment by in a sense primarily (re-)affirming the legitimacy of the EU legislature in the field of public health, as well as the ongoing UK litigation initiated in BAT. This take on events might be more accurate than the similarly sounding result of rejecting the claims of the tobacco industry. Such subtlety is important though. Because probably the highlight has been the central importance - the "decisive influence" - of the FCTC non-binding guidelines, both to EU legislature and judiciary, with the Advocate General referring to the "extremely broad latitude" afforded to FCTC States from the guidelines.

My extended analysis above reveals that there are many aspects to examine as this source - a form of international soft law - has clearly affected the design and application of EU law and policy. It was my main argument that it has been the FCTC itself that has altered the EU legitimacy dynamic by directly affecting the design and implementation of the new TPD by the Union legislature and the subsequent judicial review by the EU's judiciary. Despite my claim of a dual-effect at national and EU level, the Court subsequently was happy to construct the FCTC as a key legal source. The Poland and Philip Morris judgments particularly highlight the emergence of the FCTC as an increasingly important source in EU law and policy securing a "broad latitude" for the Union legislature as a leading public health regulator, and I have given examples of a norm-taking and norm-setting role seen through the TPD. Furthermore, I noted that a vital part of the Court's approach in regard to future

\footnotetext{
182 Dr Tonio Borg and Jane Ellison MP respectively were awarded the WHO's Director-General Special Award; see http://www.who.int/tobacco/wntd/awards2014/en/ and http://www.ash.org.uk/media-room/press-releases/:public-healthminister-jane-ellison-awarded-who-medal [Accessed 1st July, 2016]). For World No Tobacco Day 2016, the WHO was "calling on countries to get ready for plain (standardized) packaging of tobacco products," see http://www.who.int/campaigns/no-tobacco-day/2016/brochure/en/ [Accessed 1st July, 2016]. (Section 2 below defines "plain packaging".) To mark that occasion, and indicate the confluence of policies around the globe, the front cover of the May 2016 edition of Tobacco Control-a leading anti-tobacco/pro-health journal cited regularly in preparing the TPD - reads "Get Ready for Plain Packaging". See May 2016, Volume 25, Issue 3, at http://tobaccocontrol.bmj.com/content/current [Accessed 1st July, 2016].
} 
national discrepancies as barriers to a healthy market, a classic approach, also means that there will likely be a third legislative instalment within 10 years for tobacco and related products.

My analysis was however, subject to several reservations notably concerning the "decisive influence" of FCTC non-binding guidelines, and the diluting effect of the FCTC's pre-emptory role on the a priori right of EEA States to legislate in the tobacco field, including for novel or so-called 'tobacco-related' products such as e-cigarettes and refill containers (it is in fact a misnomer to refer to certain such products as tobacco-related, as they contain no tobacco whatsoever). I have also expressed serious concern as to the rigour and cogency of the Court's reasoning in dealing with proportionality and fundamental rights. In both these respects, I share such concerns with Mr Justice Green who noted the "cursory" and "conclusionary" nature. At the very least, my analysis hopefully showed that reliance on the non-binding aspects of the FCTC by the Court and Union legislature deserves further reflection, as does the interplay of expression and health as fundamental sets of (competing) rights and how these ought to be somehow reconciled. It was therefore regrettable that the CJEU did not feel the need for a 13-judge panel to clarify its case law in the areas under scrutiny.

However, the tactical manoeuvrings of the CJEU ought also to be an important part of the account, and provide explanation to some points I have raised. Certainly the process and result were a swift and timely response to industry (and Member States) claims, and because these stand as much for a political as legal statement, we must regard the TPD as stronger since the month of May. The Court's positive outcomes on the lawfulness and appropriateness of the TPD could not be guaranteed of course - not least the impact of the FCTC (Guidelines); nonetheless, they were in my view to be expected (especially in light of the three emphatic and coordinated opinions on 23 December 2015). Armed with this foresight, those charged with the management of the CJEU's affairs saw to it that the Court of Justice mirrored a strategic sense of timing in defence of the inevitable attack on the new laws. Executed by the Second Chamber three times on the same day with the same 5-judge panel each time, the coordinated response has a tangible sense of consistency and collegiality, which was vital given a troublesome gestation, delivery and birth of the directive. The Court, through Philip Morris specifically, also enabled the English High Court to make its decision, and in time for transposition. It may have been that none of these aims would come to bear if Grand Chambers had been employed.

We ought finally to consider the consequences of the rulings - as I invited at the outset. On the one hand, European countries and parliaments associated with resistance to the path of the directive and/or a certain ambivalence to aggressive (EU) tobacco control will react cautiously, perhaps negatively, in political terms and regarding legal implementation of the TPD. The timing of the major wave of EU enlargement meant that many such states joined the EU around the time of the FCTC formation and across the EEA different countries have joined at different times and have varying status; for instance, Italy and the Czech Republic both signed the FCTC on 16th June 2003 but did not ratify until 2nd July 2008 and 1st June 2012 respectively. Both these countries were among the 11 EU states - including as well Spain, Portugal and Greece - that issued detailed objections to the draft UK Regulations notified to the EU during 2014. Furthermore, the arguments of Poland and Romania along with countries that intervened in the judicial proceedings, reflects a range of values and priorities albeit a slightly naïve stance given the jurisprudence of the Court. We should not discount either the fiscal concerns of many states. EU Member States rely, in general, heavily on 
tobacco trade some very much so; for example, in 2010 collected tobacco excise duties exceeded $€ 79$ billion and in lower-income European economies such as Bulgaria, tobacco receipts reached $8 \%$ of total government revenues. ${ }^{183}$ Thus whilst certain (newer) EU countries are traditionally well- or better-behaved when it comes to obligations and compliance with directives (compared to some of the established Member States), tobacco policy is a touchy topic for nations like Hungary, Lithua nia and Slovakia, touching as it does the fiscal integrity of nations and the autonomy of its citizens to make lifestyle decisions. ${ }^{184}$ It is generally apparent of a divide exists amongst the nations of Europe in terms of the TPD, and especially as regards plain and standardised packaging. It is hoped that the WTO dispute noted earlier will, when it eventually arrives, provide a useful reference point for EU law and policy - and national legislation, notably in regards to trade mark law and public health.

On the other hand, a more probable future would be an overall strengthening of the antitobacco stance in Europe - led by the resolve of pro-tobacco control countries as they push forward with the TPD reforms and fully transpose the directive into their national systems, reflecting a perceived increased legal and political legitimacy and the catalytic effects of the WHO's FCTC. Others countries may follow as the UK, France and Ireland have already done, and exploit the "extremely broad latitude" of the FCTC Guidelines (and beyond) and the explicit scope of Article 24(2) TPD. Furthermore, just as the importance of tobacco litigation continues to extend well beyond the field of tobacco control, the latest rulings - and the TPD template - could provide political momentum for the pursuance of other national policies and an 'EU lifestyle policy'. ${ }^{185}$

However, we should not for one second imagine that tobacco law and litigation at EU-level is at an end. It is probably true that the legal and political question now is less about if the EU can legislate as such to prioritise health at the expense of market demand but the more pragmatic matter of how and through which measures. This shift of judicial emphasis was reflected in the framing of the opinions, ${ }^{186}$ and comments by the Court, when it noted "the order for reference does not give any precise ground of invalidity as regards Directive 2014/40 as a whole" and "relates exclusively to the validity of each of the provisions..., taken in isolation". ${ }^{187}$ I would suggest that the FCTC including the decisive influence of its guidelines, not only can be used to help justify the existence of the EU's right to legislate, also its manner of exercise - as illustrated by the differing methodologies deployed in the TPD. This will prove useful once more, because in any given law and policy future we can try to predict for tobacco regulation, there is an inevitability to a third TPD as national divergences would develop in either scenario I have described. This would exactly be a legitimate reason to adopt further

\footnotetext{
${ }^{183}$ See impact assessment (Appendix5, s.2.4.3 and s.1.1.7) and European Commission, Directorate General Taxation and Customs Union, “Tobacco Excise Tax Revenue as a Percentage of Total Tax Revenues”(2011). Excluding VAT, the UK Treasury collected $£ 9.551$ billion in the year 2011-12. See HMRC, Tobacco Duties Factsheet (November 2012).

${ }^{184}$ Economic and fiscal concerns were a main reason driving a large proportion of the 1,500 amendments to the TPD proposalduring the course of 2013 and 2014. See Elsmore and Obolevich n XX above. However, as noted in that literature (at 570), "The extent to which these concerns and/or amendments are "genuine" - in the sense of direct, from national level, or indirect via (tobacco) industry pressure in the sense of public choice theory-is unclear."

185 See Sections 2 and 4.7.

186 The Advocate General commented (at the start of her three opinions) that legal questions in relation to the principles of proportionality and legal certainty, and EU fundamental rights, had moved to centre stage and effectively displaced the central role accorded the suitability of Article 114 TFEU as a legal basis.

187 See Philip Morris at paragraph [55].
} 
EU harmonisation measures, and once more come within the lawful scope of Article 114 TFEU because assuming any proposed law in fact does in fact contribute to free movement or undistorted competition by addressing expected market fragmentation it will not be rendered invalid because it equally contributes to improving public health. In addition, tobacco companies have presumably been licking their wounds once more, and at time of writing they were likely to collectively appeal the $B A T$ ruling, whilst simultaneously seeking ways to promote and brand the cigarette itself while it remains lawful to make and sell. ${ }^{188}$ In the coming period, I can see the central legal debate being about the collision of fundamental rights, and particularly the interaction of the right to expression and the right to health. And that subject, even after everything the Court and Advocate General has said once more, is still open to debate.

188 It is interesting to note that the UK Regulations 2015 (see Regulation 5 specially) sets out requirements for the appearance of individual cigarettes, including the permitted colours and text, and the requirements for that text. 